\title{
Phase equilibria constraints on the melt fertility of crustal source rocks: The effect of sub-solidus water loss
}

\begin{tabular}{|r|l|}
\hline Journal: & Journal of Metamorphic Geology \\
\hline Manuscript ID: & JMG-14-0034 \\
\hline Manuscript Type: & Original Article \\
\hline Date Submitted by the Author: & $01-$ May-2014 \\
\hline Complete List of Authors: & $\begin{array}{l}\text { Webb, Gordon; University of Melbourne, School of Earth Sciences } \\
\text { Powell, Roger; University of Melbourne, School of Earth Sciences } \\
\text { McLaren, Sandra; University of Melbourne, School of Earth Sciences }\end{array}$ \\
\hline & prograde metamorphism, melting, water, anatexis, THERMOCALC \\
\hline
\end{tabular}


1. Phase equilibria constraints on the melt fertility of 2 crustal source rocks: The effect of sub-solidus water ${ }_{3}$ loss

4 G. Webb, R. Powell and S. McLaren

5 School Earth Sciences, The University of Melbourne, Vic 3010, Australia

${ }_{6}$ *Corresponding author: gwebb@student.unimelb.edu.au

7 Short title: Prograde water loss and crustal melt fertility 
9

During prograde metamorphism, free $\mathrm{H}_{2} \mathrm{O}$ generated by ongoing dehydration reactions is likely to be continuously lost from a rock primarily driven by compaction. Classical melting experiments cannot easily simulate this phenomena because all run products are ideally conserved within the experimental charge even though significant equilibration and $\mathrm{H}_{2} \mathrm{O}$ generation may occur during heating. Phase equilibria modelling is used to model the effect of subsolidus water loss on subsequent melting relationships of felsic lithologies (including metapelite, metagreywacke and metatonalite) in the suprasolidus. Subsolidus water loss drives the bulk composition towards the minimum saturation point within the wet melting field and results in significantly reduced subsequent melt generation when compared to melting experiments involving conservation of $\mathrm{H}_{2} \mathrm{O}$ in an experimental charge from some temperature well below the solidus. This effect is most obvious at $P-T$ conditions just above the solidus. The reduction in melt fertility due to subsolidus water loss causes rheologically critical thresholds to be shifted to higher temperatures(e.g. melt connectivity threshold, melt escape threshold and the solid-to-liquid transition). Subsolidus water loss is also likely to impact on crystallising melts as they cross the solidus. As a result, the $\mathrm{H}_{2} \mathrm{O}$ content of granites may not reflect the $\mathrm{H}_{2} \mathrm{O}$ contents of the magma from which they were derived. Instead they record the $\mathrm{H}_{2}$ Ocontents in the vicinity of the minimum saturation point at the $P-T$ conditions at which they crossed the solidus. keywords: prograde metamorphism, melting, water, anatexis, THERMOCALC 


\section{INTRODUCTION}

Understanding crustal melt fertility is important for developing robust models for migmatite formation, granite petrogenesis and the differentiation and evolution of the continental crust (Brown \& Fyfe, 1970; Huppert \& Sparks, 1988; Clemens, 1990;

Thompson, 1996; Sawyer, 1998; Annen et al., 2008). Hydrous felsic lithologies melt incongruently at mid- to lower-crustal depths $(10-60 \mathrm{~km})$ at temperatures attainable during high-grade metamorphism $\left(650-1000^{\circ} \mathrm{C}\right.$; Thompson \& Connolly, 1995; Thompson, 1999;

White et al., 2001). The amount of melt produced and its composition is determined by the composition of the source rock, the pressure and temperature conditions and any open system behaviour including the loss or gain of fluid, melt or solid phases. Of these, $\mathrm{H}_{2} \mathrm{O}$ content is one of the key compositional variables affecting melting behaviour in the crust (Tuttle \& Bowen, 1958; Holtz et al., 1995; Johannes \& Holtz, 1996).

Two dominant modes of melting have been identified to explain the observed characteristics of natural granites, migmatites and granulites. 'Fluid-present melting' or 'wet melting' describes the situation where a system is saturated with respect to a $\mathrm{H}_{2} \mathrm{O}$-dominated fluid phase as it crosses the wet solidus with increasing $T$ and/or $P$. In fluid-present melting the activity of $\mathrm{H}_{2} \mathrm{O}$ is effectively unity $\left(a_{\mathrm{H}_{2} \mathrm{O}} \approx 1\right)$, neglecting the proportions of other constituents in the fluid that are likely to be small, at least for most crustal conditions. The resulting melt phase is saturated with respect to $\mathrm{H}_{2} \mathrm{O}$. Fluid-present melting may occur in some migmatite terrains (especially at low P; e.g. Sawyer, 2010).

However it is not generally considered to be the dominant mode of melting in the continental crust (Clemens, 1984). By contrast, 'fluid-absent', 'vapour-absent' or 2

'dehydration' melting proceeds via reactions involving the breakdown of hydrous minerals 
(mainly muscovite, biotite and hornblende) in the absence of a free fluid $\left(a_{\mathrm{H}_{2} \mathrm{O}}<1\right)$ at higher temperatures than the wet solidus. It has been argued that fluid-absent melting is the dominant mechanism for the formation of most granite magmas, which are generally thought to have formed at high $T$ and are undersaturated with respect $\mathrm{H}_{2} \mathrm{O}$ (Clemens, 1984; Pickering \& Johnston, 1998).

Estimates of the amount of melt generated during partial melting have largely come from melting experiments on a variety of starting compositions including metapelites (Vielzeuf \& Holloway, 1988; Carrington \& Harley, 1995; Gardien et al., 1995; Pickering \& Johnston, 1998), metagreywackes (Patino-Douce \& Beard, 1996; Vielzeuf \& Montel, 1994; Montel \& Vielzeuf, 1997), tonalites (Huang \& Wyllie, 1986; Rutter \& Wyllie, 1988; Skjerlie \& Johnston, 1993; Patino-Douce, 1997; 2004) and amphibolites (Rushmer, 1991; Wolf \& Wyllie, 1994). The majority of recent experimental studies have focussed on fluid-absent melting because of its perceived importance in magma genesis and crustal differentiation. The results of these fluid-absent melting studies indicate that different crustal lithologies display markedly different melting behaviour at similar $P-T$ conditions. Furthermore, different melt fractions have been reported for compositionally-similar starting materials (e.g. Gardien et al., 1995).

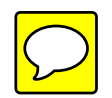

Fluid-absent melting experiments are often described as having 'no added water' or being 'vapour-absent'. This is generally achieved by pre-heating the starting material above $\sim 150^{\circ} \mathrm{C}$ for a sustained period ( $c a .24$ hours), causing any adsorbed $\mathrm{H}_{2} \mathrm{O}$ to escape, prior to sealing the experimental charge (e.g. Patino-Douce, 2004). It is then assumed that any $\mathrm{H}_{2} \mathrm{O}$ retained within the starting material is structurally bound within hydrous minerals (e.g. muscovite, biotite and amphibole). However, hydrous minerals that are stable up to $150^{\circ} \mathrm{C}$ at ambient pressures may begin to break down, via subsolidus dehydration reactions, 
as the experimental charge is heated (and pressurised) to the desired conditions of the experimental run. Because of the intentional 'closed system' nature of most high $P$ melting experiments, any $\mathrm{H}_{2} \mathrm{O}$ generated via subsolidus dehydration will be effectively trapped within the experimental charge. In this way a 'vapour absent' starting material can evolve, becoming 'fluid-present' at the experimental $P-T$ conditions. Additionally, London et al. (2012) suggested that powdered samples loaded in alr may absorb between 1 and 4 weight percent $\mathrm{H}_{2} \mathrm{O}$ before the experimental charge is sealed. It has also been suggested that water is often lost from the experimental charge via diffusion of molecular $\mathrm{H}_{2} \mathrm{O}$ through the metal casing at temperatures above $\sim 950^{\circ} \mathrm{C}$ as suggested by decreasing melt modes and increasing modal proportions of solid phases (e.g. plagioclase and garnet) with increasing $T$ during experimental runs (Patino-Douce \& Beard, 1994). The combined effects of absorption during handling and diffusive loss at high temperature work in opposite directions, thereby increasing the uncertainty in the actual $\mathrm{H}_{2} \mathrm{O}$ content inside the experimental charge during high temperature melting experiments. Furthermore, if $\mathrm{H}^{+}$is lost through the capsule rather than molecular $\mathrm{H}_{2} \mathrm{O}$, as has been suggested by some authors, this may affect the oxidation state during a melting experiment (Patino-Douce \& Beard, 1994; White et al., 2011).

An important constraint on the amount of $\mathrm{H}_{2} \mathrm{O}$ available for melting reactions during regional metamorphism can be obtained by considering the evidence for the nature of the fluid regime prior to the onset of melting. During prograde metamorphism of rocks with an 2 ally high $\mathrm{H}_{2} \mathrm{O}$ content (e.g. metapelites and metagreywackes), free $\mathrm{H}_{2} \mathrm{O}$ is likely to be continuously generated via devolatilisation reactions up to the point at which the wet solidus is crossed with increasing $T$ and/or $P$. Above this point, $\mathrm{H}_{2} \mathrm{O}$ is consumed via wet melting reactions and decreases until it is no longer stable as a free phase at progressively 
higher T. Several authors have argued that any $\mathrm{H}_{2} \mathrm{O}$ generated during subsolidus dehydration has a strong tendency to escape the source rock due to the combined effects of compaction and increasing fluid pressure (Thompson \& Connolly, 1990; Connolly, 1997;

Yardley, 2009). Decreasing $\mathrm{H}_{2} \mathrm{O}$ content with increasing metamorphic grade is observed in most metamorphic terrains providing evidence that much of the $\mathrm{H}_{2} \mathrm{O}$ generated during subsolidus dehydration escapes the system prior to the onset of melting (Miyashiro, 1961). Indeed, the loss of fluid from metamorphic terrains may be a requirement for preserving metamorphic isograds during retrograde cooling and/or decompression (Thompson, 1983; Guiraud et al., 2001). Subsolidus $\mathrm{H}_{2} \mathrm{O}$ loss (SWL) may be especially significant at the pressure conditions of the middle to lower crust where rock porosity is thought to be small $(<0.1-0.5 \%)$, and positive excursions in hydrostatic pressure above the prevailing lithostatic pressure cannot be maintained for significant time periods (Norton \& Knapp, 1977; Connolly, 1997; 2010).

Importantly, there are few existing datasets to constrain sub-solidus open system processes involving $\mathrm{H}_{2} \mathrm{O}$, and experimentally determined phase relationships do not adequately constrain melting relationships, particularly with respect to $\mathrm{H}_{2} \mathrm{O}$. Quantitative thermodynamic calculations using internally-consistent datasets can be readily employed in multicomponent systems that approach the compositional complexity of natural rocks (e.g. White \& Powell, 2002; Powell et al., 2005; White et al., 2005; White \& Powell, 2010). P-X or $T$-X pseudosections can be used to visualise the effect of changes in bulk composition, as a result of the loss of a fluid and/or solid component from the system. This kind of thermodynamic modelling has the potential to complement experimental studies to provide a clearer picture of open-system processes that are thought to occur in the continental crust. Here we use pseudosections to investigate the effect of SWL on melting relationships 
for a variety of bulk compositions representing common crustal rock types (metapelites, metagreywackes, tonalites, granodiorites). The impact of SWL on melt fertility is modelled at temperatures appropriate to partial melting during regional metamorphism at mid- to lower-crustal pressures. The modelling results are compared to the results derived from melting experiments to provide improved constraints on the nature of melting during crustal anatexis.

\section{CALCULATED PHASE RELATIONS}

Mineral equilibria calculations were undertaken using THERMOCALC 3.37i (Powell \& Holland, 1988; updated 2013) with an updated version of the internally consistent data set of Holland \& Powell (1998; data set tcds55, file created 22 November 2003). The calculations were undertaken in the chemical system

$\mathrm{Na}_{2} \mathrm{O}-\mathrm{CaO}-\mathrm{K}_{2} \mathrm{O}-\mathrm{FeO}-\mathrm{MgO}-\mathrm{Al}_{2} \mathrm{O}_{3}-\mathrm{SiO}_{2}-\mathrm{H}_{2} \mathrm{O}-\mathrm{TiO}_{2}-\mathrm{O}$ (NCKFMASHTO) of White et al. (2007). The phases considered in the calculations, and references to the activity-ccomposition models used are: garnet, biotite and silicate melt (White et al., 2007), cordierite and epidote (Holland \& Powell, 1998), orthopyroxene and magnetite (White \& Powell, 2002), muscovite (Coggon \& Holland, 2002), plagioclase - K-feldspar (Holland \& Powell, 2003), ilmenite (White et al., 2000), and hornblende (Diener et al., 2007).

Sillimanite, kyanite and quartz are pure end-member phases. Mineral abbreviations used in diagrams and in the text are: opx - orthopyroxene; g - garnet; cd - cordierite; hb hornblende; bi - biotite; mu - muscovite; ky - kyanite; sill - sillimanite; ksp - K-feldspar; pl - plagioclase; ilm - ilmenite; mt - magnetite; q - quartz; liq - silicate liquid/melt. Bulk compositions for phase equilibria modelling were derived from starting 
compositions of published melting experiments for which melt fraction $(\Phi)$ estimates are available (Table 1). The four starting compositions were chosen to represent common felsic rock types and have compositions that are comparable to the average compositions of the middle and upper crust (Fig. 1). Two metapelitic bulk compositions are from Vielzeuf \& Holloway (1988) and Gardien et al. (1995) and denoted VH88P and G95P, respectively. VH88P is modelled on a natural metapelite from the Cabo Ortegal metamorphic complex (Galicia, NW Spain) composed of quartz (39 wt\%), plagioclase (19 wt\%), kyanite (7 wt\%), muscovite (9 wt\%), biotite(21 wt\%), garnet (2 wt\%), staurolite (1 wt\%), secondary chlorite (1 wt\%) and accessory minerals (1 wt\%). VH88P is strongly peraluminous and has comparatively high molar $\mathrm{K}_{2} \mathrm{O} / \mathrm{Na}_{2} \mathrm{O}$ and high $\mathrm{FeO}$ contents. G95P is derived from a model two-mica metapelite generated from a mixture of quartz (39 wt\%), plagioclase (30 wt\%), muscovite (15 wt\%) and biotite (15 wt\%). It is weakly peraluminous and has comparatively low $\mathrm{K}_{2} \mathrm{O} / \mathrm{Na}_{2} \mathrm{O}$, high $\mathrm{SiO}_{2}$ and low $\mathrm{CaO}$. A metagreywacke bulk composition (denoted VM94G) is derived from melting experiments on a natural metagreywacke from the vallée de la Beaume (Ardèche, France) composed of quartz (40 wt\%), plagioclase (32 wt\%), and biotite (25 wt\%), and accessory minerals (3 wt\%; Vielzeuf \& Montel, 1994; Montel \& Vielzeuf, 1997). This composition is weakly peraluminous with high $\mathrm{K}_{2} \mathrm{O} / \mathrm{Na}_{2} \mathrm{O}, \mathrm{SiO}_{2}$ and low FeO. A tonalitic bulk composition (denoted PD97T) was derived from melting experiments on a natural tonalite starting material from the Sierra Nevada Batholith (Lee Vining Canyon area; Patino-Douce, 1997). The sample was reported to contain of quartz (20 wt\%), plagioclase (45 wt\%), K-feldspar (7 wt\%), hornblende (13 wt\%), biotite (13 wt\%) and accessory minerals $(2 \mathrm{wt} \%)$. PD97T is metaluminous with low $\mathrm{K}_{2} \mathrm{O} / \mathrm{Na}_{2} \mathrm{O}, \mathrm{SiO}_{2}$ and high $\mathrm{CaO}$ and $\mathrm{Na}_{2} \mathrm{O}$.

Some of the bulk compositions contain low concentrations of $\mathrm{F}, \mathrm{P}, \mathrm{Mn}$ and $\mathrm{CO}_{2}$. Small 
amounts $\mathrm{P}_{2} \mathrm{O}_{5}, \mathrm{CO}_{2}$ and $\mathrm{MnO}$ are unlikely to have a measurable effect on the melting

behaviour of felsic rocks, whereas $\mathrm{F}$ contents in the range $0.01-4 \mathrm{wt} \%$ may have the effect of lowering the solidus of granitic melts (Manning, 1981) and stabilising biotite to higher temperatures (Peterson et al., 1991). Fluorine is not currently incorporated into the activity-composition models for biotite or melt. As a result, the models presented here may differ slightly in terms of melting behaviour from the more complex starting compositions of the corresponding experiments. Furthermore, it should be noted that the melt model used here does not incorporate $\mathrm{TiO}_{2}$ or ferric iron. $\mathrm{TiO}_{2}$ is readily incorporated into biotite and oxide minerals (e.g. ilmenite and magnetite) and is important for stabilising biotite at high temperature (White et al., 2007). Hayden \& Watson (2007) investigated the incorporation of $\mathrm{TiO}_{2}$ into haplogranitic melt. Their results indicated that even for rutile-saturated bulk compositions the amount of $\mathrm{TiO}_{2}$ incorporated into the melt phase was small and as such, is unlikely to have a first order effect on melt fertility. The ferric iron content of all of the bulk compositions in this study are fixed at low values such that the only stable iron oxide minerals are ilmenite \pm magnetite.

For each starting composition the $\mathrm{H}_{2} \mathrm{O}$ content was varied to produce a low- $\mathrm{H}_{2} \mathrm{O}$ and a high- $\mathrm{H}_{2} \mathrm{O}$ end-member (Table 2). The high and low values were chosen to encompass the transition from $\mathrm{H}_{2} \mathrm{O}$ undersaturated to $\mathrm{H}_{2} \mathrm{O}$ saturated conditions at the wet solidus. Each end-member pair were then used to construct $T-M_{\mathrm{H}_{2} \mathrm{O}}$ pseudosections (Guiraud et al., 2001) for each model starting composition. Diagrams were constructed at $10 \mathrm{kbar}$ for the starting compositions VH88P, G95P and VM94G and at 8 kbar for composition PD97T to facilitate comparison with the reported experimental results. Models were also generated at 5 kbar for VH88P, G95P and VM94G and at 4 kbar for PD97T to investigate melting equilibria at low pressure. 


\section{Pseudosections}

$T-M_{\mathrm{H}_{2} \mathrm{O}}$ pseudosections calculated for compositions VH88P, G95P, VM94G at $10 \mathrm{kbar}$, and PD97T at 8 kbar over the temperature range 450 to $1100^{\circ} \mathrm{C}$ are shown in Fig. 2. The pseudosections for all four compositions have a sub horizontal $\mathrm{H}_{2} \mathrm{O}$-saturated solidus (wet-solidus). VH88P has the highest $T$ wet solidus at $\sim 680^{\circ} \mathrm{C}$. The wet solidi for G95P, VM94G and PD97T are all similar, occurring at $\sim 645^{\circ} \mathrm{C}$. In each case the wet solidus extends beyond the range of the high $\mathrm{H}_{2} \mathrm{O}$ end-member but is limited at low $\mathrm{H}_{2} \mathrm{O}$ contents by the stability of free $\mathrm{H}_{2} \mathrm{O}$. The point at which the solidus is minimally saturated with respect to $\mathrm{H}_{2} \mathrm{O}$ is referred to here as the minimum saturation point (MSP; Fig. 2). The narrow fields immediately above the wet-solidus in all four $T-M_{\mathrm{H}_{2} \mathrm{O}}$ pseudosections are low variance fields related to the underlying NCKASH univariant reaction,

$$
\mathrm{pl}+\mathrm{q}+\mathrm{H}_{2} \mathrm{O} \pm \mathrm{mu} / \mathrm{ksp}=\text { liq } .
$$

The $\mathrm{H}_{2} \mathrm{O}$-out boundaries of these 'wet-melting' fields are intersected within $10-40{ }^{\circ} \mathrm{C}$ above the wet-solidus. The upper boundaries increase in $T$ only slightly as they trend from the minimum saturation point towards the high $\mathrm{H}_{2} \mathrm{O}$ end-member for each diagram.

At $\mathrm{H}_{2} \mathrm{O}$ contents less than the value of the minimum saturation point the temperature of the solidus increases steeply as the equilibrium composition becomes increasingly undersaturated with respect to $\mathrm{H}_{2} \mathrm{O}$. Inflections in the solidus curves at low $\mathrm{H}_{2} \mathrm{O}$ contents on each of the $T-M_{\mathrm{H}_{2} \mathrm{O}}$ pseudosections correspond to changes in the modal mineralogy of low variance fields emanating from 'vapour absent' univariant reactions in the underlying NCKASH and NCKFMASH systems including, 


$$
\begin{array}{r}
\mathrm{mu}+\mathrm{pl}+\mathrm{q}=\mathrm{ksp}+\text { sill } / \mathrm{ky}+\text { liq; } \\
\mathrm{bi}+\mathrm{sill} / \mathrm{ky}+\mathrm{pl}+\mathrm{q}=\mathrm{g}+\mathrm{ksp}+\text { liq; } \\
\mathrm{bi}+\mathrm{pl}+\mathrm{q}=\mathrm{opx}+\mathrm{ksp}+\text { liq. }
\end{array}
$$

For all compositions, the subsolidus $\mathrm{H}_{2} \mathrm{O}$-out boundary trends to lower bulk $\mathrm{H}_{2} \mathrm{O}$ contents as it approaches the solidus (at the minimum saturation point) with increasing $T$ (Fig. 2). The $\mathrm{H}_{2} \mathrm{O}$-out boundary for VH88P rises steeply from $<450{ }^{\circ} \mathrm{C}$ up to the plagioclase-in boundary $\left(\sim 615^{\circ} \mathrm{C}\right)$ and then migrates towards a lower bulk $\mathrm{H}_{2} \mathrm{O}$ value as it approaches the solidus. For compositions G95P and VM94G the $\mathrm{H}_{2} \mathrm{O}$-out boundary is steep and approximately linear from $<450{ }^{\circ} \mathrm{C}$ up to the wet-solidus. The $\mathrm{H}_{2} \mathrm{O}$-out boundary for PD97T trends gradually towards lower bulk $\mathrm{H}_{2} \mathrm{O}$, with distinct inflections corresponding to muscovite-out, K-feldspar-in and hornblende-in boundaries, as it approaches the minimum saturation point at the wet solidus with increasing temperature.

The pseudosections for VH88P and G95P both contain sillimanite and kyanite. For VH88P, sillimanite is stable from the sill-ky phase transition $\left(\sim 800^{\circ} \mathrm{C}\right)$ up to $>1000^{\circ} \mathrm{C}$ at high $\mathrm{H}_{2} \mathrm{O}$ contents and is stable above $1100{ }^{\circ} \mathrm{C}$ at low $\mathrm{H}_{2} \mathrm{O}$ contents (Fig. 2 a \& b). Kyanite is stable from $800^{\circ} \mathrm{C}$ down to below $450{ }^{\circ} \mathrm{C}$ over the entire range of modelled $\mathrm{H}_{2} \mathrm{O}$ contents (0.11-14.02 mol\%). Sillimanite is stable for G95P from the sill-ky phase transition to above $1100{ }^{\circ} \mathrm{C}$ near the low- $\mathrm{H}_{2} \mathrm{O}$ end-member, but its upper limit of stability decreases to $\sim 900{ }^{\circ} \mathrm{C}$ at the high- $\mathrm{H}_{2} \mathrm{O}$ end-member. Kyanite is stable from $800{ }^{\circ} \mathrm{C}$ down to $450{ }^{\circ} \mathrm{C}$ at $\mathrm{H}_{2} \mathrm{O}$ contents below $\sim 3 \mathrm{~mol} \%$. Above this value the stability is limited by the kyanite-out boundary along the low $T$ sides of the quadrivariant bi-mu-ksp-pl-liq-ilm-q-ky and the quinivariant bi-mu-pl-liq-ilm-q-ky fields. Neither sillimanite nor kyanite are stable for 
VM94G and PD97T over the range modelled (Fig. 2 c \& d).

K-feldspar is unstable at temperatures above the solidus at high bulk $\mathrm{H}_{2} \mathrm{O}$ contents for all four modelled compositions. At bulk $\mathrm{H}_{2} \mathrm{O}$ contents close to the minimum saturation point, K-feldspar is stable over the ranges $\sim 790-1000{ }^{\circ} \mathrm{C}, \sim 700-980^{\circ} \mathrm{C}, \sim 810-990{ }^{\circ} \mathrm{C}$ and $<450-990{ }^{\circ} \mathrm{C}$ for compositions VH88P, G95P, VM94G and PD97T, respectively.

It is important to note that even at high $T\left(>1000^{\circ} \mathrm{C}\right)$ none of the bulk compositions reach their liquidus and form pure melts (including the metatonalite - PD97T; Fig. 2).

Even for the high $\mathrm{H}_{2} \mathrm{O}$ end-members the high $T$ equilibrium assemblages comprise liq-g-ilm, liq-opx-ilm, liq-opx-ilm-q and liq-hb-pl-ilm for VH88P, G95P, VM94G and PD97T, respectively. Lower variance high $T$ assemblages become increasingly stable at lower bulk $\mathrm{H}_{2} \mathrm{O}$ contents in each pseudosection.

Ilmenite is stable for all for starting compositions over the entire modelled ranges of temperature and $\mathrm{H}_{2} \mathrm{O}$ contents. The pseudosection for composition G95P contains rutile at low temperature and magnetite is stable for intermediate $\mathrm{H}_{2} \mathrm{O}$ contents between $800-880^{\circ} \mathrm{C}$. Staurolite is stable from just below to just above the solidus for composition VM94G. While these phases are involved in the NCKFMASHTO equilibria, their modal abundances (1-oxide molar basis) are always low $(<0.01)$ and are, therefore, unlikely to exert a significant influence on the melting behaviour of the system modelled.

\section{Prograde metamorphism and sub-solidus water loss}

The contours of melt and free $\mathrm{H}_{2} \mathrm{O}$ corresponding to the pseudosections in Fig. 2 are shown in Figure 3. While each $T-M_{\mathrm{H}_{2} \mathrm{O}}$ pseudosection displays distinct phase relationships in detail, the relationships between the free $\mathrm{H}_{2} \mathrm{O}$ and melt bearing regions in each case are 
broadly similar. The proportion of free $\mathrm{H}_{2} \mathrm{O}$ present along a particular prograde heating path in the subsolidus (vertical line) can be described in terms of $\mathrm{d} f / \mathrm{d} T$ (representing the change in free $\mathrm{H}_{2} \mathrm{O}$ productivity with increasing $\mathrm{T}$ ). Similarly, the amount of melt produced along a path in the suprasolidus can be described in terms of $\mathrm{d} m / \mathrm{d} T$ (i.e. change in melt productivity with increasing T; Johnson et al., 2008).

At sub-solidus conditions $\mathrm{d} f / \mathrm{d} T$ is positive from $<450{ }^{\circ} \mathrm{C}$ up to the solidus at bulk $\mathrm{H}_{2} \mathrm{O}$ values above the $\mathrm{H}_{2} \mathrm{O}$-out boundary for each of the four compositions (grey regions in Fig. 3). As a consequence, all four modelled compositions will produce free $\mathrm{H}_{2} \mathrm{O}$ along a prograde path, with fixed $\mathrm{H}_{2} \mathrm{O}$ contents, that traverses the 'free $\mathrm{H}_{2} \mathrm{O}$-stable' region (i.e. bulk $\mathrm{H}_{2} \mathrm{O}$ contents greater than the value of the minimum saturation point). At supra-solidus conditions, $\mathrm{H}_{2} \mathrm{O} \&$ melt are both stable within the narrow wet-melting fields. Within this region, $\mathrm{d} f / \mathrm{d} T$ becomes negative and the amount of free $\mathrm{H}_{2} \mathrm{O}$ decreases rapidly towards the $\mathrm{H}_{2} \mathrm{O}$-out boundary with increasing $T$. This region also corresponds to an initial increase in melt production with melt contours that are perpendicular to the $T$-axis $\left(\mathrm{d} m / \mathrm{d} T>10 \mathrm{~mol} \% / 10^{\circ} \mathrm{C}\right)$. Above the $\mathrm{H}_{2} \mathrm{O}+$ melt region the melt contours have a slope influenced by the shape of the $\mathrm{H}_{2} \mathrm{O}$-undersaturated solidus such that increases in $T$ and/or bulk $\mathrm{H}_{2} \mathrm{O}$ correspond to increased melt production.

An idealised melting experiment involves conserving all of the starting components (including the initial $\mathrm{H}_{2} \mathrm{O}$ contents) throughout the experimental run. This behaviour is represented by the conservation of subsolidus water (CSW) scenario, shown by the vertical grey arrows in Fig. 3. The water contents for the CSW scenario for VH88P, G95P and VM94G are derived from the reported water contents for the bulk starting material of the original experiments $(2.15 \mathrm{w} \%, 1.9 \mathrm{w} \%$ and $1.44 \mathrm{w} \%$, respectively; Table 2). The $\mathrm{H}_{2} \mathrm{O}$ contents of PD97T was not reported. The CSW path for this composition was chosen 
so as to intersect the observed melt fraction in the experiments (i.e. $\Phi=0.30$ melting at $950{ }^{\circ} \mathrm{C}$; Patino-Douce, 1997).

If subsolidus water loss occurs, free $\mathrm{H}_{2} \mathrm{O}$ will be incrementally lost along the prograde heating path (Guiraud et al., 2001), continuously driving the bulk composition towards the $\mathrm{H}_{2} \mathrm{O}$-out boundary. To reduce the bulk $\mathrm{H}_{2} \mathrm{O}$ contents of the source rock below the value of the $\mathrm{H}_{2} \mathrm{O}$-out boundary would require the liberation of structurally bound $\mathrm{H}_{2} \mathrm{O}$ from hydrous minerals. As there is no viable mechanism to achieve this, the subsolidus $\mathrm{H}_{2} \mathrm{O}$-out boundary effectively limits the minimum $\mathrm{H}_{2} \mathrm{O}$-contents of the source rock. As the rock crosses the solidus with increasing temperature any remaining free $\mathrm{H}_{2} \mathrm{O}$ is rapidly consumed within the wet-melting fields and the newly generated melt becomes increasingly undersaturated with respect to $\mathrm{H}_{2} \mathrm{O}$. Because such melts are effectively 'water-starved' as soon as they cross the solidus, the $\mathrm{H}_{2} \mathrm{O}$ contents of the system become fixed at the value of the minimum saturation point, if $\mathrm{H}_{2} \mathrm{O}$ loss is efficient and the porosity is small, as generally suggested. As a result an isobaric prograde heating path for a rock composition affected by SWL will involve:

1. A sub-solidus path that traverses the free $\mathrm{H}_{2} \mathrm{O}$ region at bulk $\mathrm{H}_{2} \mathrm{O}$ contents just greater than the $\mathrm{H}_{2} \mathrm{O}$-out boundary as it approaches the minimum saturation point;

2. A supra-solidus path with the bulk $\mathrm{H}_{2} \mathrm{O}$ fixed at the value of the minimum saturation point up to the maximum temperature of the system.

In natural systems, $\mathrm{H}_{2} \mathrm{O}$ may additionally be lost via incorporation into escaping melt or as part of hydrous peritectic minerals that are themselves entrained into escaping melt (Clemens \& Stevens, 2012). However, both of these mechanisms will lead to other changes in the bulk composition that cannot be determined by varying any single compositional 
variable. The appropriate diagrams for modelling such phenomena are more complex and involve varying the equilibrium bulk composition at each increment of melt- and/or mineral-loss.

The mineral mode changes along the subsolidus sections of the SWL paths were calculated along the $\mathrm{H}_{2} \mathrm{O}$-out boundary so that the bulk $\mathrm{H}_{2} \mathrm{O}$ contents continuously changes along this segment. The supra-solidus portion of the SWL path was modelled at a fixed $\mathrm{H}_{2} \mathrm{O}$ value (corresponding to the minimum saturation point; Table 2). Changes in the modal abundances of the equilibrium assemblages along the modelled CSW and SWL paths for the four starting compositions are shown in Fig. 4.

For composition VH88P the SWL heating path results in significantly less melt generation when compared with the CSW path (especially at low T; Fig. 4a \& 4b). The reduction in melt fraction along the SWL path corresponds to increases in the modal proportions of quartz, plagioclase and biotite. K-feldspar is stabilised at temperatures above $\sim 790^{\circ} \mathrm{C}$, whereas K-feldspar is completely absent in the CSW scenario. Very high $\mathrm{d} m / \mathrm{d} T$ melting $\left(20 \mathrm{~mol} \% / 10^{\circ} \mathrm{C}\right)$ along the CSW path $(\Phi<0.01$ to $\sim 0.11)$ corresponds to the $\mathrm{H}_{2} \mathrm{O}$-out boundary just above the solidus, at $\sim 680^{\circ} \mathrm{C}$. This feature is not observed along the SWL path. Moderate $\mathrm{d} m / \mathrm{d} T$ melting $\left(\sim 3 \mathrm{~mol} \% / 10^{\circ} \mathrm{C}\right)$ over the interval $790-880^{\circ} \mathrm{C}$ on the SWL path corresponds to breakdown of biotite and increased growth of garnet. Melting at higher temperatures continues to increase in a broadly monotonic fashion reaching melt fractions of $\sim 0.65$ and $\sim 0.44$ at $1000^{\circ} \mathrm{C}$ for the $\mathrm{CSW}$ and SWL paths, respectively $\left(\mathrm{d} m / \mathrm{d} T \sim 1-2 \mathrm{~mol} \% / 10^{\circ} \mathrm{C}\right)$. Interestingly, muscovite begins to breakdown below the solidus (at $\sim 615^{\circ} \mathrm{C}$, corresponding to the first appearance of plagioclase) and completely disappears just above the solidus, at $\sim 720^{\circ} \mathrm{C}$, for both the SWL and CSW paths; however, there is no significant increase in the melt fraction corresponding to the 
disappearance of muscovite from the equilibrium assemblage along either path.

The SWL path for G95P corresponds to reduced melt fertility and slight increases in the modal proportions of quartz and plagioclase at temperatures just above the solidus $\left(\sim 640^{\circ} \mathrm{C}\right)$ and an increase in the proportion of $\mathrm{K}$-feldspar at temperatures above $760{ }^{\circ} \mathrm{C}$ when compared to the CSW path (Fig. 4c \& 4d). Two steep increases in melting occur along the CSW path at low melt fraction. The first corresponds to the $\mathrm{H}_{2} \mathrm{O}$-out boundary just above the solidus $\left(\mathrm{d} m / \mathrm{d} T \sim 6-8 \mathrm{~mol} \% / 10^{\circ} \mathrm{C}\right)$. The second step corresponds to the abrupt disappearance of muscovite and the first appearance of kyanite and K-feldspar (at $\left.\sim 760{ }^{\circ} \mathrm{C} ; \mathrm{d} m / \mathrm{d} T \sim 10-20 \mathrm{~mol} \% / 10^{\circ} \mathrm{C}\right)$. Due to the negligible amount of $\mathrm{H}_{2} \mathrm{O}$ at the solidus in the SWL scenario the melt fraction remains low $(\Phi<0.02)$ until muscovite disappears at $\sim 760^{\circ} \mathrm{C}$ at which point it increases abruptly to $(\Phi \sim 0.09)$. Melting at higher temperatures continues to increase steeply with melt fractions reaching $\sim 0.69$ and $\sim 0.51$ at $1000{ }^{\circ} \mathrm{C}$ for the CSW and SWL paths, respectively $\left(\mathrm{d} m / \mathrm{d} T \sim 3-5 \mathrm{~mol} \% / 10^{\circ} \mathrm{C}\right)$.

For composition VM94G, the SWL scenario results in significantly reduced melt fertility, moderate increases in the modal proportions of quartz and plagioclase at temperatures just above the solidus (Fig. 4e \& 4f). K-feldspar increases in modal abundance and becomes stabilised over a broader temperature range $\left(\sim 805-1000^{\circ} \mathrm{C}\right)$ when compared to the CSW path $\left(\sim 905-930^{\circ} \mathrm{C}\right)$. A sharp increase in melting along the CSW path corresponds to the $\mathrm{H}_{2} \mathrm{O}$-out boundary just above the solidus (at $\sim 650{ }^{\circ} \mathrm{C} ; \mathrm{d} m / \mathrm{d} T$ $\left.\sim 8-10 \mathrm{~mol} \% / 10^{\circ} \mathrm{C}\right)$. Again, this feature is absent from the SWL path. Immediately above the solidus the melt fraction remains low $(\Phi<0.01)$ along the SWL path with an initial, gradual increase in melt fraction, beginning at $\sim 755^{\circ} \mathrm{C}$, corresponding to the first appearance of garnet and the initial breakdown of biotite $(\mathrm{d} m / \mathrm{d} T$ increasing from $<0.1 \mathrm{up}$ to $2 \mathrm{~mol} \% / 10^{\circ} \mathrm{C}$ ). A steep increase in melting, from $\Phi \approx 0.09$ to $\Phi \approx 0.19$, corresponds to 
the final disappearance of biotite and the first appearance of orthopyroxene across the temperature interval $\sim 895-910{ }^{\circ} \mathrm{C}$ for the SWL path $\left(\mathrm{d} m / \mathrm{d} T \sim 7 \mathrm{~mol} \% / 10^{\circ} \mathrm{C}\right)$. A similar step occurs along the CSW path over the same temperature interval with melting abruptly increasing from from $\Phi \approx 0.28$ to $\Phi \approx 0.36$. Above the biotite-out boundary, melt fractions climb steeply to values of $\sim 0.56$ and $\sim 0.34$ at $1000{ }^{\circ} \mathrm{C}$ for the CSW and SWL paths, respectively $\left(\mathrm{d} m / \mathrm{d} T \sim 3-4 \mathrm{~mol} \% / 10^{\circ} \mathrm{C}\right)$.

The SWL scenario for composition PD97T results in decreased melt fertility and slight increases in the modal proportions of quartz, plagioclase and K-feldspar when compared to the CSW path (Fig. $4 \mathrm{~g} \& 4 \mathrm{~h}$ ). A small, moderate increase in melt fraction, from 0.0 to $\sim 0.02$, occurs just above the solidus, at $\sim 640^{\circ} \mathrm{C}$, along the CSW path $(\mathrm{d} m / \mathrm{d} T$ $\left.\sim 5 \mathrm{~mol} \% / 10^{\circ} \mathrm{C}\right)$. Again, this initial step in melt fraction is absent from the SWL path. The melt fraction along the CSW path increases gently to 0.09 over the interval $\sim 645-840^{\circ} \mathrm{C}$ $\left(\mathrm{d} m / \mathrm{d} T \sim 0.1-0.2 \mathrm{~mol} \% / 10^{\circ} \mathrm{C}\right)$ and then abruptly increases to 0.17 between $\sim 840-850{ }^{\circ} \mathrm{C}$ $\left(\mathrm{d} m / \mathrm{d} T \sim 10 \mathrm{~mol} \% / 10^{\circ} \mathrm{C}\right)$. A similar sharp increase in melt fraction occurs along the SWL path (from $\Phi \sim 0.03$ to 0.10 ) over the same temperature interval. For both paths this step corresponds to the first appearance of orthopyroxene, the breakdown and disappearance of biotite and an increase in the modal abundance of K-feldspar. Above the biotite-out boundary melt fractions increase moderately steeply to reach $\sim 0.45$ and $\sim 0.36$ at $1000{ }^{\circ} \mathrm{C}$ for the CSW and SWL paths, respectively $\left(\mathrm{d} m / \mathrm{d} T \sim 10 \mathrm{~mol} \% / 10^{\circ} \mathrm{C}\right)$. Interestingly, hornblende modes do not noticeably decrease for either path over the calculated melting interval $\left(\sim 640-1100^{\circ} \mathrm{C}\right)$. 


\section{Melting at low pressure}

The minimum saturation point for each composition, and the corresponding SWL melting path, increases as a function of pressure. Therefore, it is not possible to create a single $P-T$ pseudosection for a bulk composition affected by SWL. Rather it is necessary to determine $T-M_{\mathrm{H}_{2} \mathrm{O}}$ phase relationships and $\mathrm{H}_{2} \mathrm{O}$ value of the minimum saturation point at each pressure of interest. As a result this method is only applicable to the consideration of isobaric melting paths. To examine the effect of pressure on the phase equilibria, temperature-mode diagrams were generated for the SWL scenario along prograde isobaric heating paths for VH88P, G95P and VM94G at 5 kbar and PD97T at 4 kbar (Fig. 5).

At 5 kbar, VH88P (SWL) produces very little melt $(\Phi<0.03)$ between the solidus, at $\sim 690^{\circ} \mathrm{C}$, and $\sim 775^{\circ} \mathrm{C}\left(\mathrm{d} m / \mathrm{d} T \ll 0.1 \mathrm{~mol} \% / 10^{\circ} \mathrm{C}\right)$. The melt fraction then rises sharply to $\Phi \approx 0.07$ at $\sim 780^{\circ} \mathrm{C}\left(\mathrm{d} m / \mathrm{d} T \sim 10-20 \mathrm{~mol} \% / 10^{\circ} \mathrm{C}\right)$. This step corresponds to the disappearance of sillimanite from the equilibrium assemblage, a sharp decrease in the modal abundance of biotite, an increase in the modal abundance of cordierite and the first appearance of garnet. This feature is absent from the SWL scenario for composition VH88P at 10 kbar. Above $\sim 780^{\circ} \mathrm{C}$ the melt fraction increases moderately steeply reaching $\Phi$ $\approx 0.67$ at $\sim 1000^{\circ} \mathrm{C}\left(\mathrm{dm} / \mathrm{d} T \sim 2-3 \mathrm{~mol} \% / 10^{\circ} \mathrm{C} ;\right.$ c.f. 0.44 for VH88P at $\left.10 \mathrm{kbar}\right)$.

The melt fraction for composition G95P (SWL) at 5 kbar remains low $(<0.01)$ between the solidus $\left(\sim 655^{\circ} \mathrm{C}\right)$ and $\sim 675^{\circ} \mathrm{C}\left(\mathrm{d} m / \mathrm{d} T \ll 0.1 \mathrm{~mol} \% / 10^{\circ} \mathrm{C}\right)$. Between $675-680^{\circ} \mathrm{C}$ the melt fraction jumps abruptly to $\sim 0.07\left(\mathrm{~d} m / \mathrm{d} T \sim 10-20 \mathrm{~mol} \% / 10^{\circ} \mathrm{C}\right)$. This step corresponds to the disappearance of muscovite and the first appearance of sillimanite in the equilibrium assemblage. A similar high $\mathrm{d} m / \mathrm{d} T$ step is observed at $\sim 760^{\circ} \mathrm{C}$ in the $\mathrm{SWL}$ melting curve for G95P at 10 kbar. From $680-835^{\circ} \mathrm{C}$ the melt fraction increases gradually 
to $0.19\left(\mathrm{~d} m / \mathrm{d} T \sim 0.5-0.7 \mathrm{~mol} \% / 10^{\circ} \mathrm{C}\right)$. From $835^{\circ} \mathrm{C}$ the melting curve begins to increase steeply corresponding to the breakdown and disappearance of biotite and the first appearance of orthopyroxene in the equilibrium assemblage $\left(\mathrm{d} m / \mathrm{d} T \sim 8 \mathrm{~mol} \% / 10^{\circ} \mathrm{C}\right)$.

Melting then proceeds with a steep slope reaching 0.70 at $\sim 1000{ }^{\circ} \mathrm{C}(\mathrm{d} m / \mathrm{d} T$ $\sim 4-5 \mathrm{~mol} \% / 10^{\circ} \mathrm{C}$; c.f. 0.51 for G95P at $\left.10 \mathrm{kbar}\right)$.

At 5 kbar, the melting curve for composition VM94G (SWL) increases slightly, from $\Phi=0.0$ to 0.02 , between the solidus $\left(675^{\circ} \mathrm{C}\right)$ and the first appearance of garnet in the equilibrium assemblage at $785^{\circ} \mathrm{C}\left(\mathrm{d} m / \mathrm{d} T \ll 0.1 \mathrm{~mol} \% / 10^{\circ} \mathrm{C}\right)$. Between $785-840{ }^{\circ} \mathrm{C}$ the melt fraction increases sharply to 0.22 corresponding to the first appearance of orthopyroxene and the breakdown and disappearance of biotite from the equilibrium assemblage $(\mathrm{d} m / \mathrm{d} T$ $\left.\sim 8-10 \mathrm{~mol} \% / 10^{\circ} \mathrm{C}\right)$. Above $840^{\circ} \mathrm{C}$ the melting curve rises steeply to reach 0.60 at $\sim 1000^{\circ} \mathrm{C}$ $\left(\mathrm{d} m / \mathrm{d} T \sim 4 \mathrm{~mol} \% / 10^{\circ} \mathrm{C} ;\right.$ c.f. 0.34 for G95P at $\left.10 \mathrm{kbar}\right)$.

At 4 kbar PC97T (SWL) produces very little melt $(<0.02)$ between the solidus, at $\sim 655^{\circ} \mathrm{C}$, and $795{ }^{\circ} \mathrm{C}$ corresponding to the first appearance of orthopyroxene $(\mathrm{d} m / \mathrm{d} T$ $\left.\ll 0.1 \mathrm{~mol} \% / 10^{\circ} \mathrm{C}\right)$. Between $795-805^{\circ} \mathrm{C}$ the melt fraction increases sharply to $0.11(\mathrm{~d} m / \mathrm{d} T$ $\left.\sim 10-15 \mathrm{~mol} \% / 10^{\circ} \mathrm{C}\right)$. This interval corresponds to the rapid breakdown and disappearance of biotite and an increase in the abundance of K-feldspar and orthopyroxene in the equilibrium assemblage. Above $805^{\circ} \mathrm{C}$, the melt fraction increases moderately steeply to reach 0.47 at $\sim 1000{ }^{\circ} \mathrm{C}$ (c.f. 0.36 for G95P at $10 \mathrm{kbar}$ ). 


\section{CRUSTAL MELT FERTILITY}

\section{Comparisons with melting experiments}

The experimentally derived melt fractions corresponding to VH88P, G95P, VM94G and PD97T are shown in Figs. $3 \&$ 6. As previously noted, the starting $\mathrm{H}_{2} \mathrm{O}$ contents for the melting experiments reported by Patino-Douce (1997) are not known, so it is not possible to make a comparison with the modelled CSW melting path for PD97T. Nevertheless, it is still useful to compare an inferred CSW path from matching the reported experimental melt fraction with the modelled SWL scenario.

Vielzeuf \& Holloway (1988) infer a very steep increase in melt fraction, from $\Phi=0.10$ to 0.60 over the temperature range $850-900^{\circ} \mathrm{C}$ corresponding to a biotite-out "reaction" (i.e. $\mathrm{bi}+$ sill $/ \mathrm{ky}+\mathrm{pl}+\mathrm{q} \rightarrow \mathrm{liq}+\mathrm{g}+\mathrm{ksp}$; Fig. $6 \mathrm{a}$ ). Above $900^{\circ} \mathrm{C}$, these authors describe a melting 'plateau' corresponding to the gradual breakdown of sillimanite and garnet. Neither of these features are observed for the CSW path for VH88P which displays broadly monotonic melting behpringr above $800^{\circ} \mathrm{C}$. At temperatures higher than $\sim 950^{\circ} \mathrm{C}$, they report lower melt fractions than the $\mathrm{VH} 88 \mathrm{P}()$ melting curve. A similar misfit is observed between the the experimental results of Vielzeuf \& Montel (1994) and the modelled CSW path for VM94 at $1000^{\circ} \mathrm{C}$ (Fig. 6c). Experiments above $950{ }^{\circ} \mathrm{C}$ were not reported in Gardien et al. (1995) or Patino-Douce (1997), so any high $T$ effect cannot be assessed for

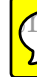
studies. Nevertheless, the generation of lower than predicted melt fractions at high $T$ is consistent with observations from other experiments that melt modes often decrease at temperatures above $950{ }^{\circ} \mathrm{C}$ (possibly due to diffusive $\mathrm{H}_{2} \mathrm{O}$-loss through the wall of the experimental capsule; Patino-Douce \& Beard, 1994).

The experimental melt fraction estimates reported by Gardien et al. (1995) show a 


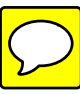

456

general trend of increasing melting with increasing $T$ that broadly corresponds to the CSW melting curve for composition G95P (Fig. 6b). Interestingly, both the CSW and SWL melting curves for composition G95P record a steep increase in melt fraction at $\sim 760^{\circ} \mathrm{C}$, corresponding to the mu-out boundary with increasing $\mathrm{T}$, while the reported experimental melt fraction actually decreases by $5 \%$ between $750^{\circ} \mathrm{C}$ and $800^{\circ} \mathrm{C}$ before increasing at higher T. The melting estimates of Vielzeuf \& Montel (1994) are slightly above the corresponding VM94G() melting curve at temperatures below $\sim 900^{\circ} \mathrm{C}$ (Fig. $6 \mathrm{~b}$ ).

Importantly, the experimentally-derived melt fractions for all starting compositions are higher than the corresponding SWL melting curves as a function of $\mathrm{T}$. This general result is consistent with the assumption that SWL constrained melting represents a minimum melting end-member for a particular bulk composition.

The general advantages and limitations of melting experiments and phase equilibria modelling have been discussed in detail elsewhere (e.g. Johnson et al., 2008; White et al., 2011), so the following discussion focusses on the issues that are specific to estimating crustal melt fertility. The differences between the experimental estimates and the modelled CSW melting curves can be understood in terms of the different limitations inherent for each approach.

A key assumption of most melting experiments is that the analysed composition of the starting material is representative of the equilibrating bulk composition at experimental run conditions. As previously discussed above, the combined effects of $\mathrm{H}_{2} \mathrm{O}$ absorption into powders during handling as well as diffusive $\mathrm{H}_{2} \mathrm{O}$ loss through the experimental casing at high temperature may result in significant changes in the actual $\mathrm{H}_{2} \mathrm{O}$ content of a given melting experiment. The CSW scenarios reported here represent idealised melting 
experiments that are unaffected by these undesirable experimental phenomena.

Detailed melting experiments are labour and time intensive with individual experiments often taking several weeks to approach equilibration (e.g. Patino-Douce, 2004). As a result, the total number of data points generated is usually low and performing repeat experiments at the same $P-T$ conditions is uncommon making it difficult to assess the statistical significance or the reproducibility of any single melting estimate. By contrast, phase equilibria modelling allows the determination of melt modes over a range of $P-T-X$ conditions for which the constituent phase models are calibrated. This allows for the calculation of continuous melting curves along a particular $P-T$ path of interest.

Melt fractions for each experimental charge are typically estimated either by mass balance calculations or by graphical assessment of the proportion of melt in two-dimensional back-scattered electron scans. Both methods have high analytical uncertainties that may be difficult to quantify (e.g. Vielzeuf \& Montel, 1994). Quantitative determination of melt fractions from experimental data is particularly problematic at low melt fractions due to the small size of melt/glass volumes that may be observed and analysed within the matrix of the experimental charge. As a result, experimental studies can often only approximate the degree of melting occurring at temperatures near the solidus. This constraint does not apply to phase equilibria modelling where the degree of melting can be calculated in detail from the solidus up to high temperatures.

The NCKFMASH melt model used in this study is constrained by well calibrated experimental data on unary, binary and ternary subsystems (Holland \& Powell, 2001). It can, therefore, expected to satisfactorily describe the topology of the melt bearing fields in NCKFMASHTO, if not, for example, the precise PT position of fields. As previously 
discussed, the effects of $\mathrm{TiO}_{2}$ and $\mathrm{Fe}^{3+}$ on the modelled melt fertility are likely to be small and certainly less than the uncertainties inherent in the determination of experimental estimates on the corresponding natural rock compositions. The influence of other minor components (e.g. Mn, F, Cl, P, B) on melting behaviour cannot be assessed with the models used here and in any case it is unlikely that any of these components (with the possible exception of $\mathrm{F}$ ) will significantly affect melting behaviour at the low concentrations reported for the experimental starting compositions (shown in Table 1). We, therefore, argue that the modelled melting curves presented here represent reliable estimates of the melt fertility of the starting compositions under conditions of CSW and SWL.

\section{Estimates of crustal melt fertility}

It is clear that the overall 'shapes' of the melting curves for the CSW and SWL scenarios for each starting composition are similar and reflect similar underlying melt-producing equilibria (Fig. 6). Inflections in the melting curves occur at similar $T$ indicating that they are largely independent of bulk $\mathrm{H}_{2} \mathrm{O}$ content over the ranges modelled. The key difference between the CSW and SWL curves, in each case, is that the CSW melting curve contains an initial steep increase, just above the solidus, corresponding to the disappearance of free $\mathrm{H}_{2} \mathrm{O}$ from the equilibrium assemblage. This initial melting step effectively increases the baseline for subsequent melting but does not significantly affect the shape of the curve at higher T. The most obvious observation that can be made from comparing these curves is that CSW paths that incorporate excess free $\mathrm{H}_{2} \mathrm{O}$ will yield more melt than the corresponding SWL path.

The SWL melting curves for each starting composition at high and low pressure are 
shown in Figure 7. With decreasing pressure the solidus migrates to higher $T$ (shown by the grey and black arrows in Fig. 7), while at the same time the $\mathrm{H}_{2} \mathrm{O}$ solubility of the melt phase increases. At low pressure, SWL constrained heating paths intersect key melting equilibria at lower $T$ compared to the corresponding high $P$ paths (cf. SWL versus CSW paths at constant $P$; Fig. 6). This is because the underlying fluid-absent melting reactions have a positive slope in $P-T$ space. The resulting melting curves show increased melt generation in the lower pressure scenarios for all starting compositions. This is likely to be a general result that is applicable to most felsic rock compositions.

As noted above there is no obvious geological mechanism that would cause the bulk composition to contain less $\mathrm{H}_{2} \mathrm{O}$ than the value corresponding to the minimum saturation point. As a result the SWL path results in the minimum melt fertility scenario for a given source rock. Increasing melt fertility above the minimum defined by efficient SWL may be achieved via the retention of sub-solidus $\mathrm{H}_{2} \mathrm{O}$ or the addition of $\mathrm{H}_{2} \mathrm{O}$ to the system at temperatures above the solidus (compare paths A, B \& C in Fig. 8).

$\mathrm{H}_{2} \mathrm{O}$ may be released from a source rock with a higher $T$ solidus into an adjacent rock with a lower $T$ solidus (White et al., 2005). For example, at 10 kbar composition VH88P intersects its wet-solidus at $\sim 680^{\circ} \mathrm{C}$ whereas the solidus for composition G95P occurs at $\sim 640{ }^{\circ} \mathrm{C}$. If these two compositions represent hypothetical adjacent source regions subjected to the same heating path, VH88P could provide up to $3 \% \mathrm{H}_{2} \mathrm{O}$ to $\mathrm{G} 95 \mathrm{P}$ over the temperature interval between their respective solidi. assuming the source rocks were in equal proportions, this would result in a significant increase in the melt fertility of the G95P source rock $\left(\sim 10 \%\right.$ more melt at $800^{\circ} \mathrm{C}, \sim 15 \%$ more melt at $\left.1000^{\circ} \mathrm{C}\right)$. Water may also be added to a particular source rock via dewatering of migrating melts. During cooling and crystallisation water is released as the melt composition intersects the $\mathrm{H}_{2} \mathrm{O}$ saturated fields 
near the solidus (e.g. paths D \& E in Fig. 8). $\mathrm{H}_{2} \mathrm{O}$ saturation in melt is strongly dependent on pressure (Tuttle \& Bowen, 1958; Johannes \& Holtz, 1996). Therefore, the volume of water released by a crystallising melt will depend on the initial $\mathrm{H}_{2} \mathrm{O}$ content of the melt and the pressure at which the melt intersects the $\mathrm{H}_{2} \mathrm{O}$-in boundary. These three mechanisms may result in greater melt fertility than is defined by a SWL-moderated minimum melting curve. However, under most geological conditions SWL paths and melt fertility are likely to apply.

The modelling presented here does not take into consideration the effect of melt loss on melt fertility of felsic rocks as this process involves modification of several compositional vectors the cannot be represented on a simple $T-M_{\mathrm{H}_{2} \mathrm{O}}$ diagram. The loss of melt will cause the bulk composition to become more residual with the largest compositional change likely to be a decrease in water content due to the hydrous nature of the melt derived from melting of felsic rocks (White \& Powell, 2002; 2010).

\section{DISCUSSION and CONCLUSIONS}

\section{General conclusions}

The water content of the rock comprises the sum of free $\mathrm{H}_{2} \mathrm{O}$ and structurally-bound $\mathrm{H}_{2} \mathrm{O}$ residing in hydrous minerals (e.g. biotite, muscovite and hornblende). While free $\mathrm{H}_{2} \mathrm{O}$ can be lost from a source rock (due to compaction, deformation, migrating porosity, etc.), structurally-bound $\mathrm{H}_{2} \mathrm{O}$ is only made mobile when the hydrous host mineral becomes unstable due to changes in the $P-T-X$ conditions at equilibrium. This may occur at sub solidus and/or suprasolidus conditions. Above the solidus, any $\mathrm{H}_{2} \mathrm{O}$ liberated by the breakdown of hydrous phases is incorporated into the melt phase (until it is $\mathrm{H}_{2} \mathrm{O}$ 
saturated). The $\mathrm{H}_{2} \mathrm{O}$ contents of the systems described here cannot evolve to be less than the value of the minimum saturation point without also losing melt and/or solid phases (Fig. 8). In this way subsolidus water loss can be viewed as defining the minimum $\mathrm{H}_{2} \mathrm{O}$ condition for a particular bulk composition that has undergone prograde heating. A corollary of this is that the subsolidus water loss path defines the minimum melt fertility of a rock, at least prior to melt loss.

Most melting experiments are likely to conserve any $\mathrm{H}_{2} \mathrm{O}$ generated by devolatilisation of hydrous minerals as the experimental charge is heated and pressurised from ambient temperatures up to the conditions of the experimental run. Given the likelihood that subsolidus water loss is a significant phenomena affecting prograde metamorphic rocks, most experimentally derived melting curves will tend to overestimate the melt fertility of the starting material at the onset of melting within the continental crust. The modelled curves presented here allow subsolidus water loss to be taken into account and, therefore, allow determination of the minimum melting relationships for compositions of interest.

\section{Implications for melt connectivity, melt loss and the rheology of the crust during anatexis}

An important consequence of the reduced melt fertility implied by the subsolidus water loss model is that critical melt thresholds will be intersected at significantly higher temperatures (Fig. 6). At low-melt fractions melt will initially form in isolated domains along grain edges and corners between reactant phases (Mehnert et al., 1973). As the melt fraction increases these isolated melt volumes begin to coalesce eventually forming an interconnected network through the rock volume (Vigneresse et al., 1996). Rosenberg \& Handy (2005) identified a 
melt connectivity threshold which occurs at $\Phi \approx 0.07$ and corresponds to $\sim 80 \%$ of grain boundaries containing melt. Experimental data suggests that rocks experience significant loss of strength between the onset of melting and the melt connectivity threshold (from $\sim 800 \mathrm{MPa}$ down to $\sim 200 \mathrm{MPa}$; Rosenberg \& Handy, 2005). It follows that rocks having experienced subsolidus water loss will remain comparatively stronger at higher temperatures than rocks that have not. For the bulk compositions modelled here the differences in the temperature of the melt connectivity threshold range from $<10^{\circ} \mathrm{C}$ to $>150{ }^{\circ} \mathrm{C}$. Such a relationship between degree of melting, temperature and strength is likely to significantly influence the rheological behaviour of crust undergoing regional metamorphism and anatexis.

Higher degrees of melting are associated with critical thresholds governing melt segregation and the transition from a solid to a liquid rheology. The melt escape threshold refers to the melt fraction at which melt is able to segregate from the source (Vigneresse et al., 1996). The melt escape threshold is likely to depend on a number of factors including viscosity and strain rate but is likely to occur at $\Phi \sim 0.2-0.25$ (Sawyer, 1994; Vigneresse et al., 1996). The 'solid-to-liquid transition' is the melt content at the transition from a solid-supported to a liquid-supported structure (Rosenberg \& Handy, 2005). The solid-to-liquid transition occurs at $\Phi \sim 0.4-0.6$. Both the melt escape threshold and the solid-to-liquid transition will be shifted to higher temperatures for a rock that has experienced subsolidus water loss. 


\section{Subsolidus water loss during magma crystallisation}

The discussion so far has concerned the consequences of subsolidus water loss during prograde heating, however crystallising magmas may also experience subsolidus water loss.

595

Large amounts of $\mathrm{H}_{2} \mathrm{O}$ may be generated as a magma approaches and then crosses the solidus if a magma had an initially high $\mathrm{H}_{2} \mathrm{O}$ content. The magma is rapidly converted to solids $+\mathrm{H}_{2} \mathrm{O}$ across the narrow melt $+\mathrm{H}_{2} \mathrm{O}$ fields just above the wet solidus (Paths D \& E in Fig. 8). Even at upper crustal conditions the inter-grain porosity is likely to be small and the tendency for free $\mathrm{H}_{2} \mathrm{O}$ to escape the now solid rock volume is likely to be high (Connolly, 1997). The escape of free $\mathrm{H}_{2} \mathrm{O}$ will cause the bulk $\mathrm{H}_{2} \mathrm{O}$ contents to decrease towards the minimum saturation point. Further cooling will take the rock across the $\mathrm{H}_{2} \mathrm{O}$-out boundary and the $\mathrm{H}_{2} \mathrm{O}$ contents will become fixed. An important consequence of this is that the final $\mathrm{H}_{2} \mathrm{O}$ contents of the crystallised solid (e.g. a tonalite) will not reflect its $\mathrm{H}_{2} \mathrm{O}$ content when it was a magma but rather reflects the water contents in the vicinity of the minimum saturation point. This would mean that analysing the $\mathrm{H}_{2} \mathrm{O}$ contents of granites collected in the field may tell us nothing about the $\mathrm{H}_{2} \mathrm{O}$ contents of the original magma.

\section{ACKNOWLEDGEMENTS}

RP acknowledges support from Australian Research Council DP0987731. SM acknowledges support from the Australian Research Council DP0987765 


\section{${ }_{611}$ References}

Annen, C., Blundy, J. D., Stephen, R. \& Sparks, R. S. J., 2008. The sources of granitic melt in Deep Hot Zones. Transactions of the Royal Society of Edinburgh: Earth Sciences, 97, 297-309.

Brown, G. C. \& Fyfe, W. S., 1970. The production of granitic melts during ultrametamorphism. Contributions to Mineralogy and Petrology, 28(4), 310-318.

Carrington, D. P. \& Harley, S. L., 1995. Partial melting and phase relations in high-grade metapelites: An experimental petrogenetic grid in the KFMASH system. Contributions to Mineralogy and Petrology, 120(3-4), 270-291.

Clemens, J. D., 1984. Water contents of silicic to intermediate magmas. Lithos, 17, 273-287.

Clemens, J. D., 1990. The granulite - granite connexion, Granulites and crustal evolution, pp. 25-36. Springer Netherlands.

Clemens, J. D. \& Stevens, G., 2012. What controls chemical variation in granitic magmas? Lithos, pp. 1-13.

Coggon, R. \& Holland, T. J. B., 2002. Mixing properties of phengitic micas and revised garnet-phengite thermobarometers. Journal of Metamorphic Geology, 20(7), 683-696.

Connolly, J. A. D., 1997. Devolatilization-generated fluid pressure and deformation-propagated fluid flow during prograde regional metamorphism. Journal of Geophysical Research: Solid Earth, 102(B8), 18149-18173. 
Connolly, J. A. D., 2010. The mechanics of metamorphic fluid expulsion. Elements, 6(3), 165-172.

Diener, J. F. A., Powell, R., White, R. W. \& Holland, T. J. B., 2007. A new thermodynamic model for clino- and orthoamphiboles in the system Na2O-CaO-FeO-MgO-Al2O3-SiO2-H2O-O. Journal of Metamorphic Geology, 25(6), 631-656.

Gardien, V., Thompson, A. B., Grujic, D. \& Ulmer, P., 1995. Experimental melting of biotite + plagioclase + quartz \pm muscovite assemblages and implications for crustal melting. Journal of Geophysical Research: Solid Earth, 100(B8), 15581-15591.

Guiraud, M., Powell, R. \& Rebay, G., 2001. H2O in metamorphism and unexpected behaviour in the preservation of metamorphic mineral assemblages. Journal of Metamorphic Geology, 19(4), 445-454.

Hayden, L. A. \& Watson, E. B., 2007. Rutile saturation in hydrous siliceous melts and its bearing on Ti-thermometry of quartz and zircon. Earth and Planetary Science Letters, 258(3-4), 561-568.

Holland, T. J. B. \& Powell, R., 1998. An internally consistent thermodynamic data set for phases of petrological interest. Journal of Metamorphic Geology, 16(3), 309-343.

Holland, T. J. B. \& Powell, R., 2001. Calculation of phase relations involving haplogranitic melts using an internally consistent thermodynamic dataset. Journal of Petrology, 42(4), 673-683.

Holland, T. J. B. \& Powell, R., 2003. Activity-composition relations for phases in 
petrological calculations: An asymmetric multicomponent formulation. Contributions to Mineralogy and Petrology, 145(4), 492-501.

Holtz, F., Behrens, H., Dingwell, D. B. \& Johannes, W., 1995. H20 solubility in haplogranitic melts: Compositional, pressure, and temperature dependence. American Mineralogist, 80, 94-108.

Huang, W. L. \& Wyllie, P. J., 1986. Phase-relationships of gabbro-tonalite-granite-water at 15 kbar with applications to differentiation and anatexis. American Mineralogist, 71, 301-316.

Huppert, H. E. \& Sparks, R. S. J., 1988. The generation of granitic magmas by intrusion of basalt into continental crust. Journal of Petrology, 29(3), 599-624.

Johannes, W. \& Holtz, F., 1996. Petrogenesis and experimental petrology of granitic rocks, Springer, Berlin.

Johnson, T. E., White, R. W. \& Powell, R., 2008. Partial melting of metagreywacke: a calculated mineral equilibria study. Journal of Metamorphic Geology, 26(8), 837-853.

London, D., Morgan, VI, G. B. \& Acosta-Vigil, A., 2012. Experimental simulations of anatexis and assimilation involving metapelite and granitic melt. Lithos, 153, 292-307.

Manning, D., 1981. The effect of fluorine on liquidus phase relationships in the system Qz-Ab-Or with excess water at $1 \mathrm{~kb}$. Contributions to Mineralogy and Petrology, .

Mehnert, K. R., Büsch, W. \& Schneider, G., 1973. Initial melting at grain boundaries of quartz and feldspar in gneisses and granulites. Neues Jahrb. Mineral. Monatsh, 4, 165-183. 
Miyashiro, A., 1961. Evolution of metamorphic belts. Journal of Petrology, 2(3), 277-311.

Montel, J.-M. \& Vielzeuf, D., 1997. Partial melting of metagreywackes, Part II. Compositions of minerals and melts. Contributions to Mineralogy and Petrology, 128(2-3), 176-196.

Norton, D. \& Knapp, R., 1977. Transport phenomena in hydrothermal systems; the nature of porosity. American Journal of Science, 277, 937-981.

Patino-Douce, A. E., 1997. Generation of metaluminous A-type granites by low-pressure melting of calc-alkaline granitoids. Geology, 25(8), 743-746.

Patino-Douce, A. E., 2004. Vapor-absent melting of tonalite at 15-32 kbar. Journal of Petrology, 46(2), 275-290.

Patino-Douce, A. E. \& Beard, J. S., 1994. H2O loss from hydrous melts during fluid-absent piston cylinder experiments. American Mineralogist, 79, 585-588.

Patino-Douce, A. E. \& Beard, J. S., 1996. Effects of P, f(O2) and Mg/Fe ratio on dehydration melting of model metagreywackes. Journal of Petrology, 37(5), 999-1024.

Peterson, J. W., Chacko, T. \& Kuehner, S. M., 1991. The effects of fluorine on the vapor-absent melting of phlogopite + quartz; implications for deep-crustal processes. American Mineralogist, 76(3-4), 470-476.

Pickering, J. M. \& Johnston, D. A., 1998. Fluid-absent melting behavior of a two-mica metapelite: experimental constraints on the origin of Black Hills granite. Journal of Petrology, 39(10), 1787-1804. 
Powell, R. \& Holland, T. J. B., 1988. An internally consistent dataset with uncertainties and correlations: 3. Applications to geobarometry, worked examples and a computer program. Journal of Metamorphic Geology, 6, 173-204.

Powell, R., Guiraud, M. \& White, R. W., 2005. Truth and beauty in metamorphic phase equilibria: Conjugate variables and phase diagrams. Canadian Mineralogist, 43, 21-33.

Rosenberg, C. L. \& Handy, M. R., 2005. Experimental deformation of partially melted granite revisited: implications for the continental crust. Journal of Metamorphic Geology, 23, 19-28.

Rudnick, R. L. \& Gao, S., 2003. Composition of the continental crust. In: Treatise on Geochemistry, (eds Rudnick, R. L., Holland, H. D. \& Turekian, K. K.), pp. 1-64. Elsevier. Rushmer, T., 1991. Partial melting of two amphibolites: Contrasting experimental results under fluid-absent conditions. Contributions to Mineralogy and Petrology, 107(1), 41-59.

Rutter, M. J. \& Wyllie, P. J., 1988. Melting of vapour-absent tonalite at 10 kbar to simulate dehydration-melting in the deep crust. Nature, 331(6152), 159-160.

Sawyer, E. W., 1994. Melt segregation in the continental crust. Geology, 22(11), 1019.

Sawyer, E. W., 1998. Formation and evolution of granite magmas during crustal reworking: The significance of diatexites. Journal of Petrology, 39(6), 1147-1167.

Sawyer, E. W., 2010. Migmatites formed by water-fluxed partial melting of a leucogranodiorite protolith: Microstructures in the residual rocks and source of the fluid. Lithos, 116(3-4), 273-286. 
Skjerlie, K. P. \& Johnston, A. D., 1993. Fluid-absent melting behavior of an F-rich tonalitic gneiss at mid-crustal pressures: Implications for the generation of anorogenic granites. Journal of Petrology, 34(4), 785-815.

Thompson, A. B., 1983. Fluid-absent metamorphism. Journal of the Geological Society, 140(4), 533-547.

Thompson, A. B., 1996. Fertility of crustal rocks during anatexis. Transactions of the Royal Society of Edinburgh: Earth Sciences, 87(1-2), 1-10.

Thompson, A. B., 1999. Some time-space relationships for crustal melting and granitic intrusion at various depths. Geological Society, London, Special Publications, 168(1), 7-25.

Thompson, A. B. \& Connolly, J. A. D., 1990. Metamorphic fluids and anomalous porosities in the lower crust. Tectonophysics, 182(1-2), 47-55.

Thompson, A. B. \& Connolly, J. A. D., 1995. Melting of the continental crust: Some thermal and petrological constraints on anatexis in continental collision zones and other tectonic settings. Journal of Geophysical Research: Solid Earth, 100(B8), 15565-15579.

Tuttle, O. F. \& Bowen, N. L., 1958. Origin of Granite in the light of experimental studies in the system NaAlSi3O8-KAlSi3O8-SiO2-H2O, GSA Memoirs, pp. 1-146. Geological Society of America.

Vielzeuf, D. \& Holloway, J. R., 1988. Experimental determination of the fluid-absent melting relations in the pelitic system. Contributions to Mineralogy and Petrology, 98, 257-276. 
Vielzeuf, D. \& Montel, J.-M., 1994. Partial melting of metagreywackes. Part I. Fluid-absent experiments and phase relationships. Contributions to Mineralogy and Petrology, 117(4), 375-393.

Vigneresse, J. L., Barbey, P. \& Cuney, M., 1996. Rheological transitions during partial melting and crystallization with application to felsic magma segregation and transfer. Journal of Petrology, 37(6), 1579-1600.

White, R. W. \& Powell, R., 2002. Melt loss and the preservation of granulite facies mineral assemblages. Journal of Metamorphic Geology, 20(7), 621-632.

White, R. W. \& Powell, R., 2010. Retrograde melt-residue interaction and the formation of near-anhydrous leucosomes in migmatites. Journal of Metamorphic Geology, 28(6), 579-597.

White, R. W., Pomroy, N. E. \& Powell, R., 2005. An in situ metatexite-diatexite transition in upper amphibolite facies rocks from Broken Hill, Australia. Journal of Metamorphic Geology, 23(7), 579-602.

White, R. W., Powell, R. \& Holland, T. J. B., 2001. Calculation of partial melting equilibria in the system $\mathrm{Na} 2 \mathrm{O}-\mathrm{CaO}-\mathrm{K} 2 \mathrm{O}-\mathrm{FeO}-\mathrm{MgO}-\mathrm{Al} 2 \mathrm{O} 3-\mathrm{SiO} 2-\mathrm{H} 2 \mathrm{O}$ (NCKFMASH). Journal of Metamorphic Geology, 19(2), 139-153.

White, R. W., Powell, R. \& Holland, T. J. B., 2007. Progress relating to calculation of partial melting equilibria for metapelites. Journal of Metamorphic Geology, 25(5), 511-527.

White, R. W., Powell, R., Holland, T. J. B. \& Worley, B. A., 2000. The effect of TiO2 and Fe2O3 on metapelitic assemblages at greenschist and amphibolite facies conditions: 
mineral equilibria calculations in the system

K2O-FeO-MgO-Al2O3-SiO2-H2O-TiO2-Fe2O3. Journal of Metamorphic Geology, 18(5), 497-511.

White, R. W., Stevens, G. \& Johnson, T. E., 2011. Is the crucible reproducible? Reconciling melting experiments with thermodynamic calculations. Elements, 7(4), 241-246.

Wolf, M. B. \& Wyllie, P. J., 1994. Dehydration-melting of amphibolite at 10 kbar: the effects of temperature and time. Contributions to Mineralogy and Petrology, 115(4), 369-383.

Yardley, B. W. D., 2009. The role of water in the evolution of the continental crust. Journal of the Geological Society, 166(4), 585-600. 


\section{Page 37 of 49}

\section{${ }_{765}$ TABLES}

Table 1. Starting compositions used in this study in wt.\% and equivalent NCKFMASHTO mol.\% values. The compositions are and the corresponding experimental studies are as follows: VH88P high-Al metapelite from Vielzeuf \& Holloway (1988), G95P - low-Al metapelite from Gardien et al. (1995), VM94G - metagreywacke from Vielzeuf \& Montel (1994), and PD97T - metatonalite from Patino-Douce (1997).

\begin{tabular}{|c|c|c|c|c|c|c|c|c|}
\hline \multirow{2}{*}{$\begin{array}{l}\text { Sample } \\
\text { Units }\end{array}$} & \multicolumn{2}{|c|}{ VH88P } & \multicolumn{2}{|c|}{ G95P } & \multicolumn{2}{|c|}{ VM94G } & \multicolumn{2}{|c|}{ PD97T } \\
\hline & wt. $\%$ & mol. \% & wt. $\%$ & mol. \% & wt. $\%$ & mol. \% & wt. $\%$ & mol. \% \\
\hline $\mathrm{SiO}_{2}$ & 64.35 & 66.64 & 70.04 & 72.14 & 69.99 & 72.27 & 61.48 & 66.56 \\
\hline $\mathrm{Al}_{2} \mathrm{O}_{3}$ & 18.13 & 11.06 & 14.92 & 9.06 & 12.96 & 7.89 & 17.07 & 10.87 \\
\hline $\mathrm{Fe}_{2} \mathrm{O}_{3}$ & - & - & - & - & 0.45 & - & - & - \\
\hline $\mathrm{FeO}$ & 6.26 & 5.42 & 3.65 & 3.14 & 4.42 & 4.16 & 5.92 & 5.35 \\
\hline $\mathrm{MgO}$ & 2.44 & 3.77 & 1.39 & 2.13 & 2.36 & 3.64 & 2.68 & 4.32 \\
\hline $\mathrm{MnO}$ & 0.09 & - & 0.09 & - & 0.06 & - & 0.11 & - \\
\hline $\mathrm{CaO}$ & 1.52 & 1.69 & 1.79 & 1.98 & 1.67 & 1.85 & 5.39 & 6.24 \\
\hline $\mathrm{Na}_{2} \mathrm{O}$ & 1.66 & 1.67 & 2.65 & 2.65 & 2.95 & 2.95 & 3.88 & 4.07 \\
\hline $\mathrm{K}_{2} \mathrm{O}$ & 2.56 & 1.69 & 3.18 & 2.09 & 2.41 & 1.59 & 2.57 & 1.77 \\
\hline $\mathrm{TiO}_{2}$ & 0.82 & 0.64 & 0.38 & 0.29 & 0.7 & 0.54 & 0.9 & 0.73 \\
\hline $\mathrm{P}_{2} \mathrm{O}_{5}$ & - & - & - & - & 0.2 & - & - & - \\
\hline $\mathrm{CO}_{2}$ & - & - & - & - & 0.1 & - & - & - \\
\hline water & 2.15 & 7.42 & 1.9 & 6.52 & 1.43 & 4.92 & - & - \\
\hline $\mathrm{F}$ & - & - & - & - & 0.09 & - & - & - \\
\hline S & - & - & - & - & 0.067 & - & - & - \\
\hline $\mathrm{B}(\mathrm{ppm})$ & - & - & - & - & 20 & - & - & - \\
\hline Total & 99.98 & 100.00 & 99.99 & 100.00 & 99.857 & 99.81 & 99.89 & 100.00 \\
\hline
\end{tabular}


Table 2. Compositions used to construct pseudosections (in mol.\%).

\begin{tabular}{|c|c|c|c|c|c|c|c|c|c|c|c|c|}
\hline Figure & Composition & Diagram & $\mathrm{H}_{2} \mathrm{O}$ & $\mathrm{SiO}_{2}$ & $\mathrm{Al}_{2} \mathrm{O}_{3}$ & $\mathrm{CaO}$ & $\mathrm{MgO}$ & $\mathrm{FeO}$ & $\mathrm{K}_{2} \mathrm{O}$ & $\mathrm{Na}_{2} \mathrm{O}$ & $\mathrm{TiO}_{2}$ & $\mathrm{O}$ \\
\hline \multicolumn{13}{|c|}{ Figures $2 \& 3$} \\
\hline \multirow[t]{2}{*}{ (a) } & VH88P & $T-M_{\mathrm{H}_{2}} \mathrm{O}$ lhs & 0.11 & 71.90 & 11.93 & 1.82 & 4.07 & 5.85 & 1.82 & 1.80 & 0.69 & 0.01 \\
\hline & & $T-M_{\mathrm{H}_{2}} \mathrm{O}$ rhs & 14.02 & 61.88 & 10.27 & 1.57 & 3.50 & 5.03 & 1.57 & 1.55 & 0.59 & 0.01 \\
\hline \multirow[t]{2}{*}{ (b) } & G95P & $T-M_{\mathrm{H}_{2}} \mathrm{O}$ lhs & 0.11 & 76.94 & 9.67 & 2.11 & 3.35 & 2.27 & 2.23 & 2.82 & 0.31 & 0.20 \\
\hline & & $T-M_{\mathrm{H}_{2}} \mathrm{O}$ rhs & 13.80 & 66.39 & 8.34 & 1.82 & 2.89 & 1.96 & 1.92 & 2.44 & 0.27 & 0.17 \\
\hline \multirow[t]{2}{*}{ (c) } & VM94G & $T-M_{\mathrm{H}_{2} \mathrm{O}}$ lhs & 0.52 & 75.62 & 8.25 & 1.93 & 3.81 & 4.35 & 1.66 & 3.09 & 0.56 & 0.20 \\
\hline & & $T-M_{\mathrm{H}_{2}} \mathrm{O}$ rhs & 12.41 & 66.58 & 7.26 & 1.70 & 3.36 & 3.83 & 1.46 & 2.72 & 0.50 & 0.17 \\
\hline \multirow[t]{2}{*}{ (d) } & PD97T & $T-M_{\mathrm{H}_{2} \mathrm{O}}$ lhs & 0.50 & 66.22 & 10.83 & 6.22 & 4.30 & 5.33 & 1.76 & 4.06 & 0.73 & 0.05 \\
\hline & & $T-M_{\mathrm{H}_{2} \mathrm{O}} \mathrm{rhs}$ & 9.92 & 59.95 & 9.81 & 5.63 & 3.90 & 4.83 & 1.60 & 3.67 & 0.66 & 0.05 \\
\hline \multicolumn{13}{|c|}{ Figure 4} \\
\hline (a) & VH88P - CSW & $\operatorname{mode}(X)-\mathrm{T}$ & 7.42 & 66.63 & 11.06 & 1.69 & 3.77 & 5.42 & 1.69 & 1.67 & 0.64 & 0.01 \\
\hline (b) & VH88P - SWL & $\operatorname{mode}(X)-\mathrm{T}$ & 3.45 & 69.50 & 11.53 & 1.76 & 3.93 & 5.65 & 1.76 & 1.74 & 0.67 & 0.01 \\
\hline (c) & G95P - CSW & $\operatorname{mode}(X)-\mathrm{T}$ & 6.52 & 72.00 & 9.05 & 1.97 & 3.13 & 2.12 & 2.08 & 2.64 & 0.29 & 0.19 \\
\hline (d) & G95P - SWL & $\operatorname{mode}(X)-\mathrm{T}$ & 4.08 & 73.88 & 9.28 & 2.03 & 3.22 & 2.18 & 2.14 & 2.71 & 0.30 & 0.19 \\
\hline (e) & VM94G - CSW & $\operatorname{mode}(X)-\mathrm{T}$ & 5.28 & 72.01 & 7.85 & 1.84 & 3.63 & 4.14 & 1.58 & 2.94 & 0.54 & 0.19 \\
\hline (f) & VM94G - SWL & $\operatorname{mode}(X)-\mathrm{T}$ & 2.78 & 73.91 & 8.06 & 1.89 & 3.72 & 4.25 & 1.62 & 3.02 & 0.55 & 0.19 \\
\hline (g) & PD97T - CSW & $\operatorname{mode}(X)-\mathrm{T}$ & 3.19 & 64.43 & 10.54 & 6.05 & 4.19 & 5.19 & 1.71 & 3.95 & 0.71 & 0.05 \\
\hline (h) & PD97T - SWL & $\operatorname{mode}(X)-\mathrm{T}$ & 2.57 & 64.84 & 10.61 & 6.09 & 4.21 & 5.22 & 1.72 & 3.97 & 0.71 & 0.05 \\
\hline \multicolumn{13}{|c|}{ Figure 5} \\
\hline (a) & VH88P - SWL & $\operatorname{mode}(X)-\mathrm{T}$ & 3.47 & 69.48 & 11.53 & 1.76 & 3.93 & 5.65 & 1.76 & 1.74 & 0.67 & 0.01 \\
\hline (b) & G95P - SWL & $\operatorname{mode}(X)-\mathrm{T}$ & 3.55 & 74.29 & 9.34 & 2.04 & 3.23 & 2.19 & 2.15 & 2.73 & 0.30 & 0.18 \\
\hline (c) & VM94G - SWL & $\operatorname{mode}(X)-\mathrm{T}$ & 2.88 & 73.84 & 8.05 & 1.88 & 3.72 & 4.25 & 1.62 & 3.02 & 0.55 & 0.19 \\
\hline (d) & PD97T - SWL & $\operatorname{mode}(X)-\mathrm{T}$ & 2.48 & 64.90 & 10.62 & 6.10 & 4.22 & 5.22 & 1.73 & 3.98 & 0.72 & 0.05 \\
\hline
\end{tabular}




\section{FIGURE CAPTIONS}

Fig. 1 Harker plots of mol.\% oxides, molar $\mathrm{K}_{2} \mathrm{O} / \mathrm{Na}_{2} \mathrm{O}$ and ASI (molar

$\left.\mathrm{Al}_{2} \mathrm{O}_{3} /\left(\mathrm{CaO}+\mathrm{Na}_{2} \mathrm{O}+\mathrm{K}_{2} \mathrm{O}\right)\right)$ for the starting compositions: VH88P - metapelite, G95P

- metapelite, VM94G - metagreywacke and PD97T - metatonalite. L, M and U

represent the estimated average compositions of the lower-, middle- and upper-crust, respectively, of Rudnick \& Gao (2003). All values are plotted on an anhydrous basis.

Fig. 2 Calculated NCKFMASHTO $T-M_{\mathrm{H}_{2} \mathrm{O}}$ pseudosections for the compositions: (a) VH88P - metapelite, (b) G95P - metapelite and (c) VM94G - metagreywacke at 10 kbar and (d) PD97T - metatonalite at 8 kbar (see Table 2). The dashed line indicates the solidus for each diagram. The white dot indicates the locus of the minimum saturation point for each diagram.

Fig. 3 Calculated contours for the modal abundances of melt (solid lines) and free $\mathrm{H}_{2} \mathrm{O}$ (dashed lines) for the compositions: (a) VH88P - metapelite, (b) G95P metapelite, (c) VM94G - metagreywacke and (d) PD97T - metatonalite (see Table 2). The dark grey areas represent the regions over which free-water is stable. The grey arrows represent the path followed for heating in a closed system with the $\mathrm{H}_{2} \mathrm{O}$ contents fixed at the value reported for the experimental starting composition. The $\mathrm{H}_{2} \mathrm{O}$ contents for the tonalitic bulk composition, (d), is unknown so the $\mathrm{H}_{2} \mathrm{O}$ contents were determined so that $30 \%$ melt is generated at $950{ }^{\circ} \mathrm{C}$ as reported in Patino-Douce (1997). As with Fig. 2 the white dot indicates the locus of the minimum saturation point for each diagram. The black arrows represent heating combined with subsolidus water loss. The stars represent melt fraction estimates with increasing temperature derived from the corresponding melting experiments (assuming 
uncertainty in the $\mathrm{H}_{2} \mathrm{O}$ contents only; see text for discussion).

Fig 4 Calculated molecular proportions of phases $(X)$ with increasing temperature for the four compositions: VH88P, G95P and VM94G at 10 kbar and PD97T at 8 kbar under conditions of conservation of water () and sub-solidus water loss (SWL). The dashed vertical line indicates the solidus for each diagram.

Fig 5 Calculated molecular proportions of phases $(X)$ with increasing temperature for the four compositions: VH88P, G95P and VM94G at 5 kbar and PD97T at 4 kbar under conditions of sub-solidus water loss (SWL). The solidus is at the left edge for each diagram.

Fig 6 Comparison of the CSW and SWL melt fraction curves (shown in figure 5) with the available experimental estimates for the four compositions VH88P, G95P and VM94G at $10 \mathrm{kbar}$ and PD97T at $8 \mathrm{kbar}$. The horizontal dashed lines indicate the melt fractions corresponding to the solid-liquid transition (SLT) and melt connectivity threshold (MCT; both after Rosenberg \& Handy, 2005) and the melt escape threshold (MET; after Vigneresse et al., 1996). The arrows indicate the difference in the temperature of the MCT between the CSW and SWL scenarios (see text for discussion).

Fig 7 Comparison of the melt fraction curves with increasing temperature at low $P$ (light grey curve) and high $P$ (dark grey curve) for the four compositions VH88P, G95P and VM94G (5 kbar and $10 \mathrm{kbar})$ and PD97T at (4 kbar and $8 \mathrm{kbar})$. The respective solidi at each pressure are indicated by the corresponding grey arrows. The position of the MCT is shown by the horizontal dashed line. 


\section{Page 41 of 49}

Fig 8 Schematic diagram showing the relationships between various melting paths (dark grey dotted lines) and crystallisation paths (light grey dotted lines) as a function of water contents. Thin grey lines represent melt contours (increasing to the top-right of the diagram). The striped area is inaccessible because $\mathrm{H}_{2} \mathrm{O}$ contents less than this value are unobtainable without invoking changes in other compositional vectors (e.g. via melt and or solid segregation; see text for discussion). 

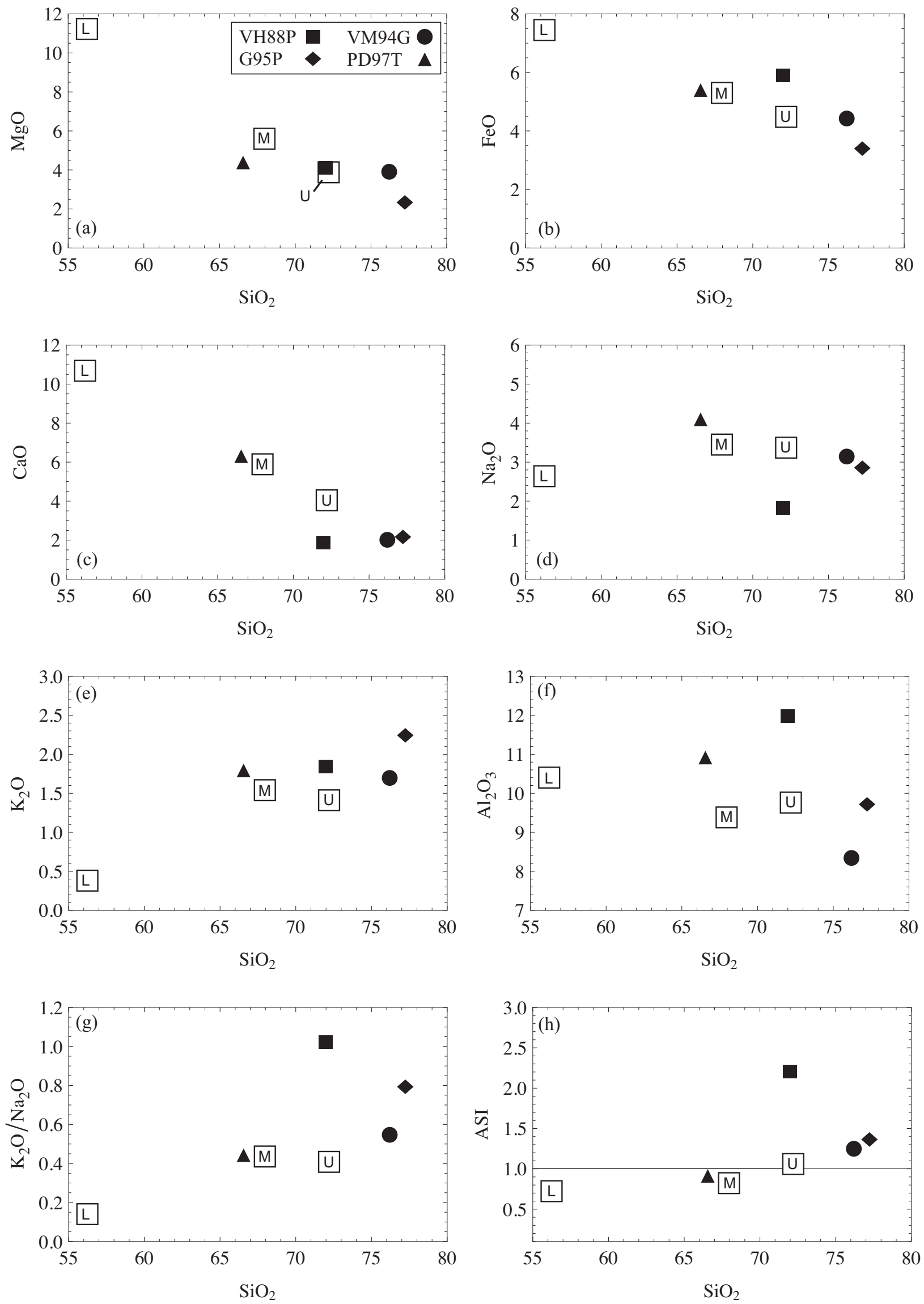

Figure 1. 


\section{Page 43 of 49}
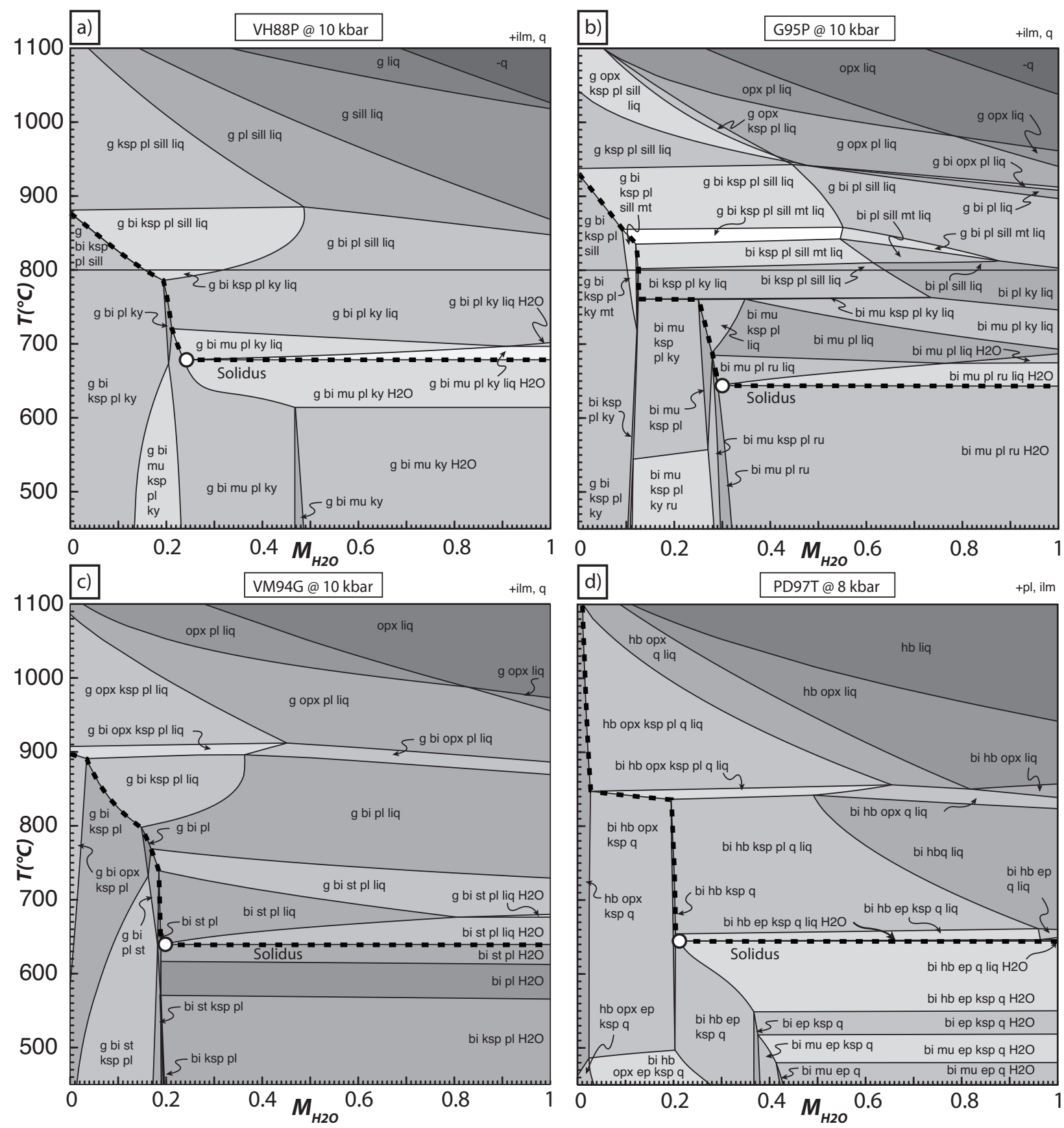

Figure 2. 

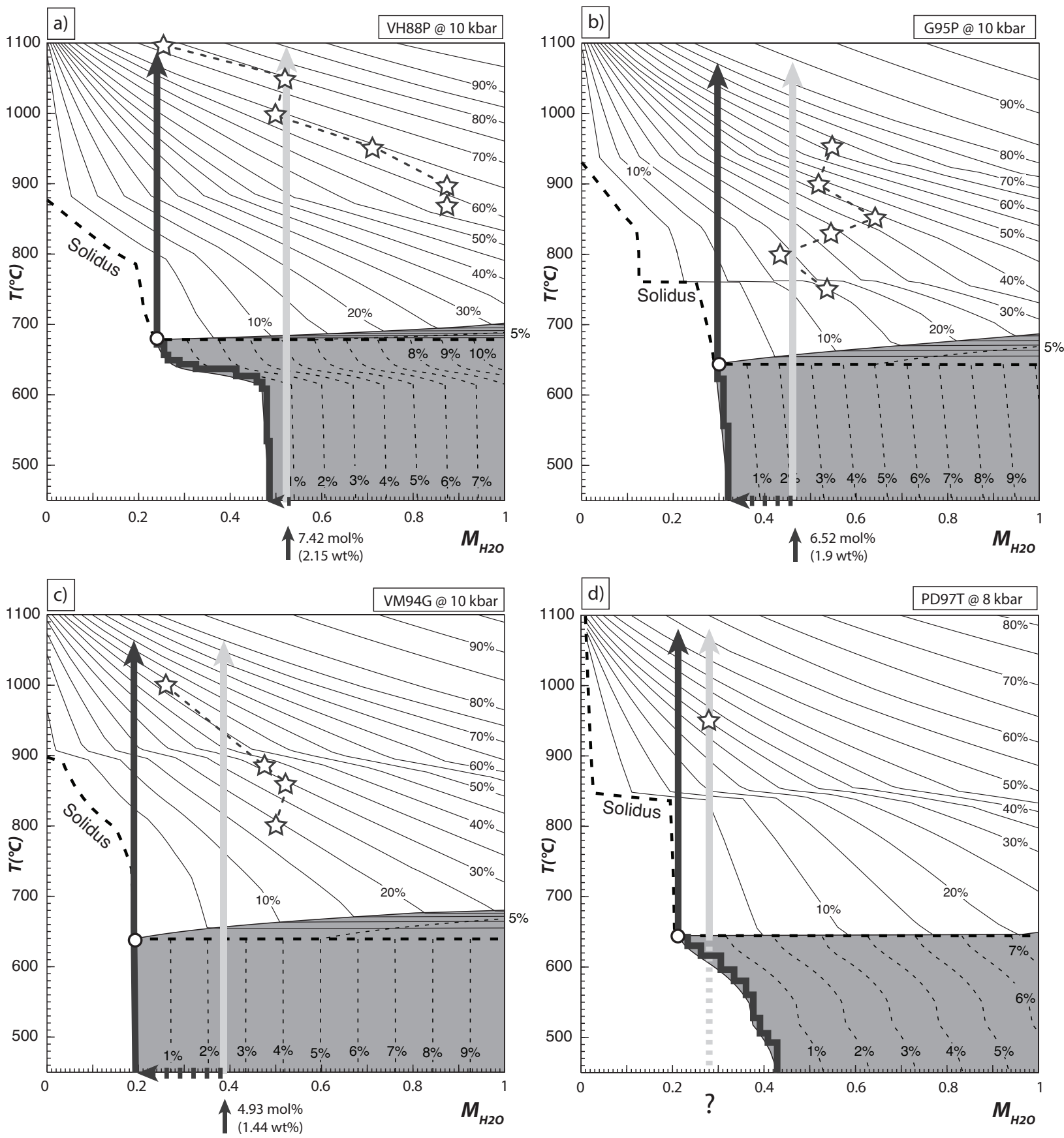

Figure 3. 

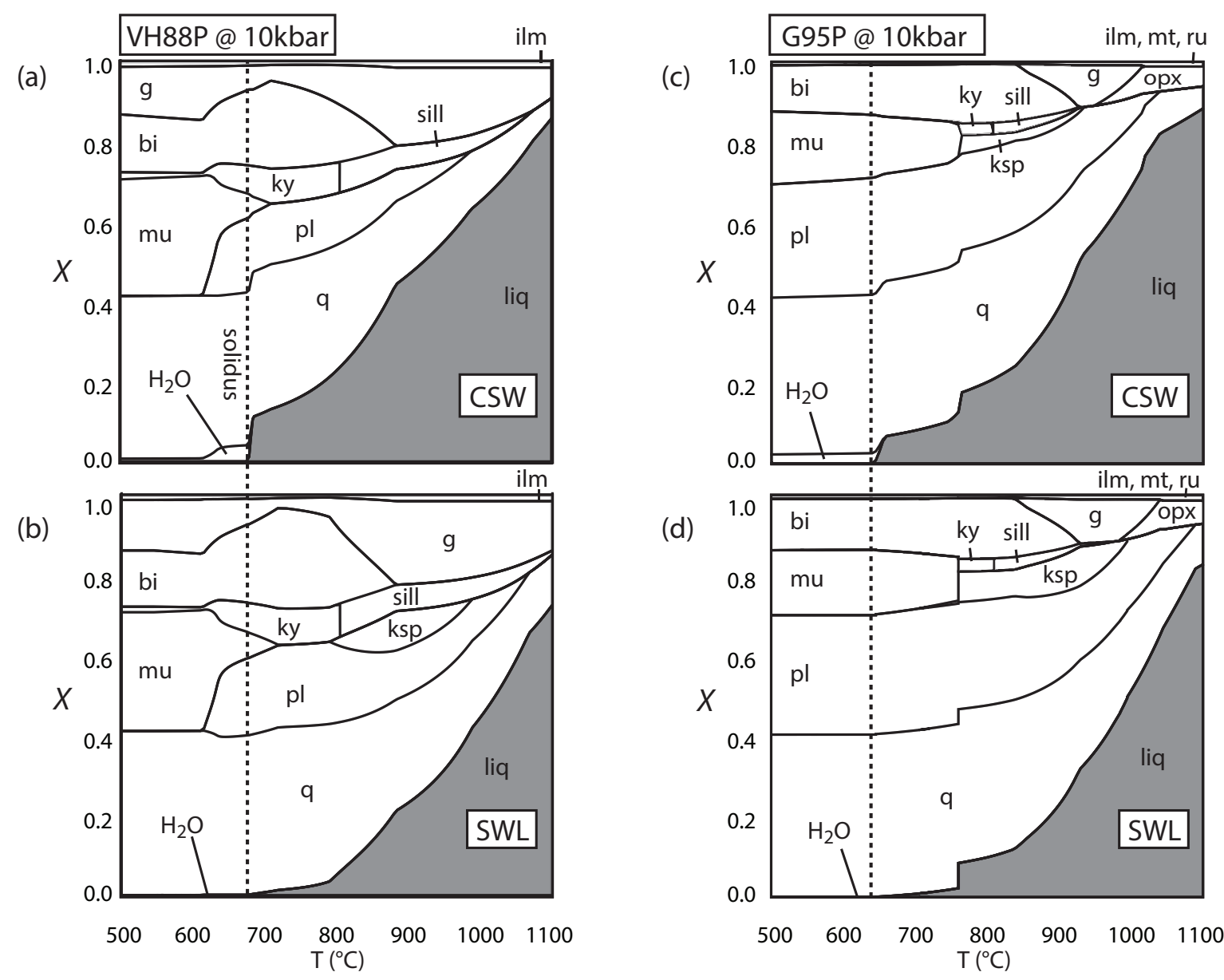

(d)
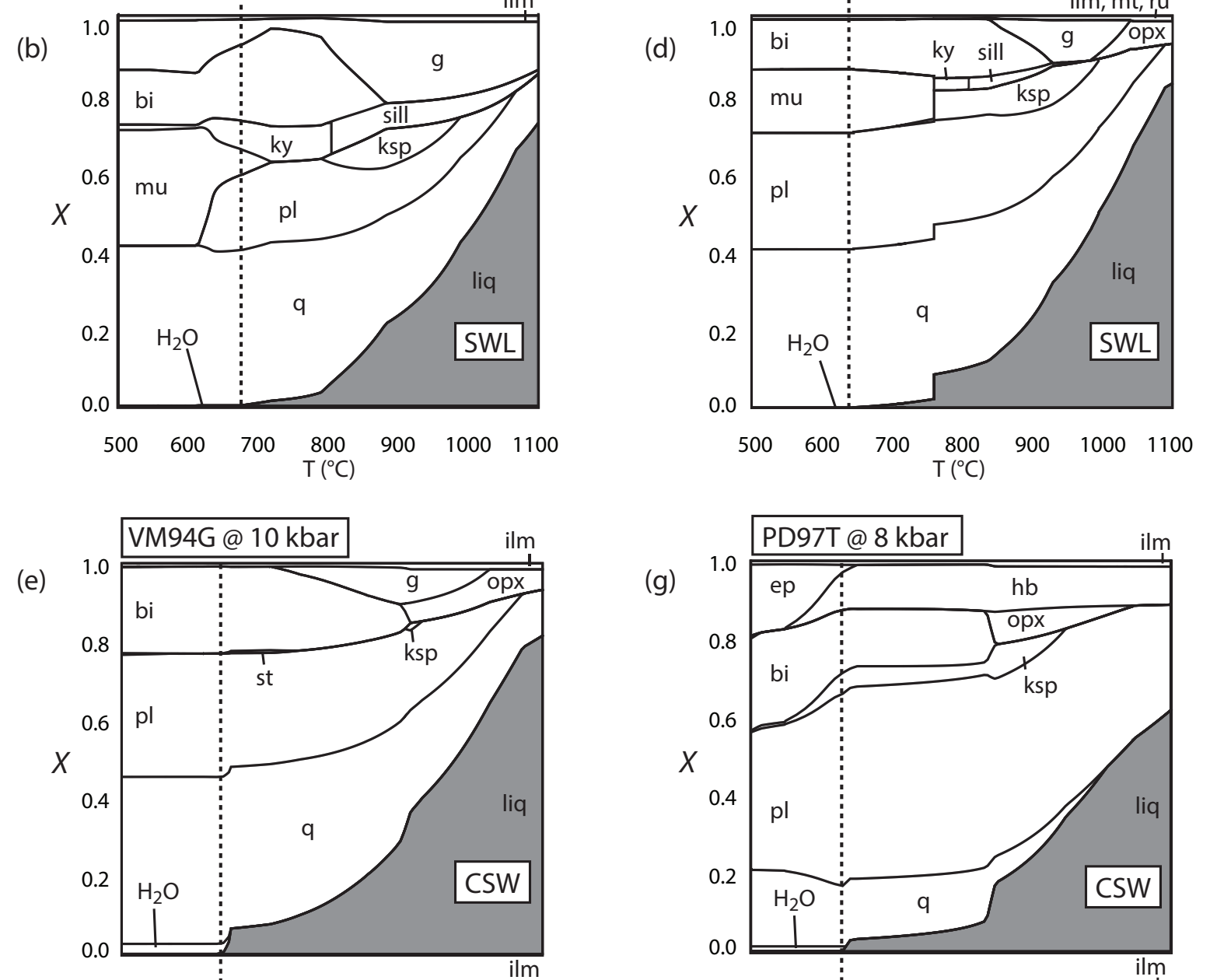

(f)

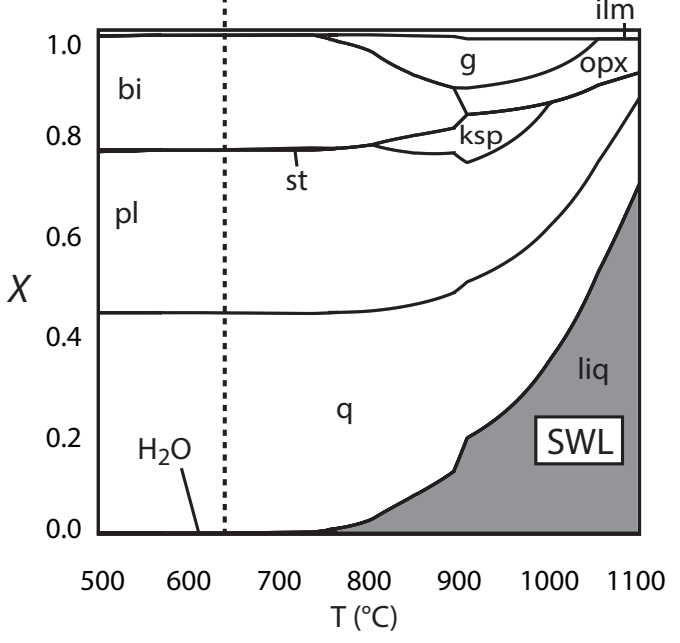

(h)

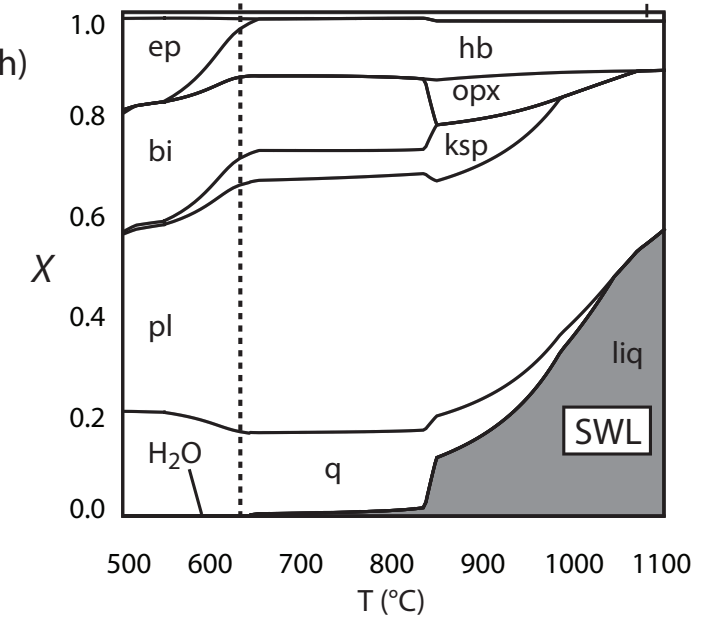

Figure 4. 

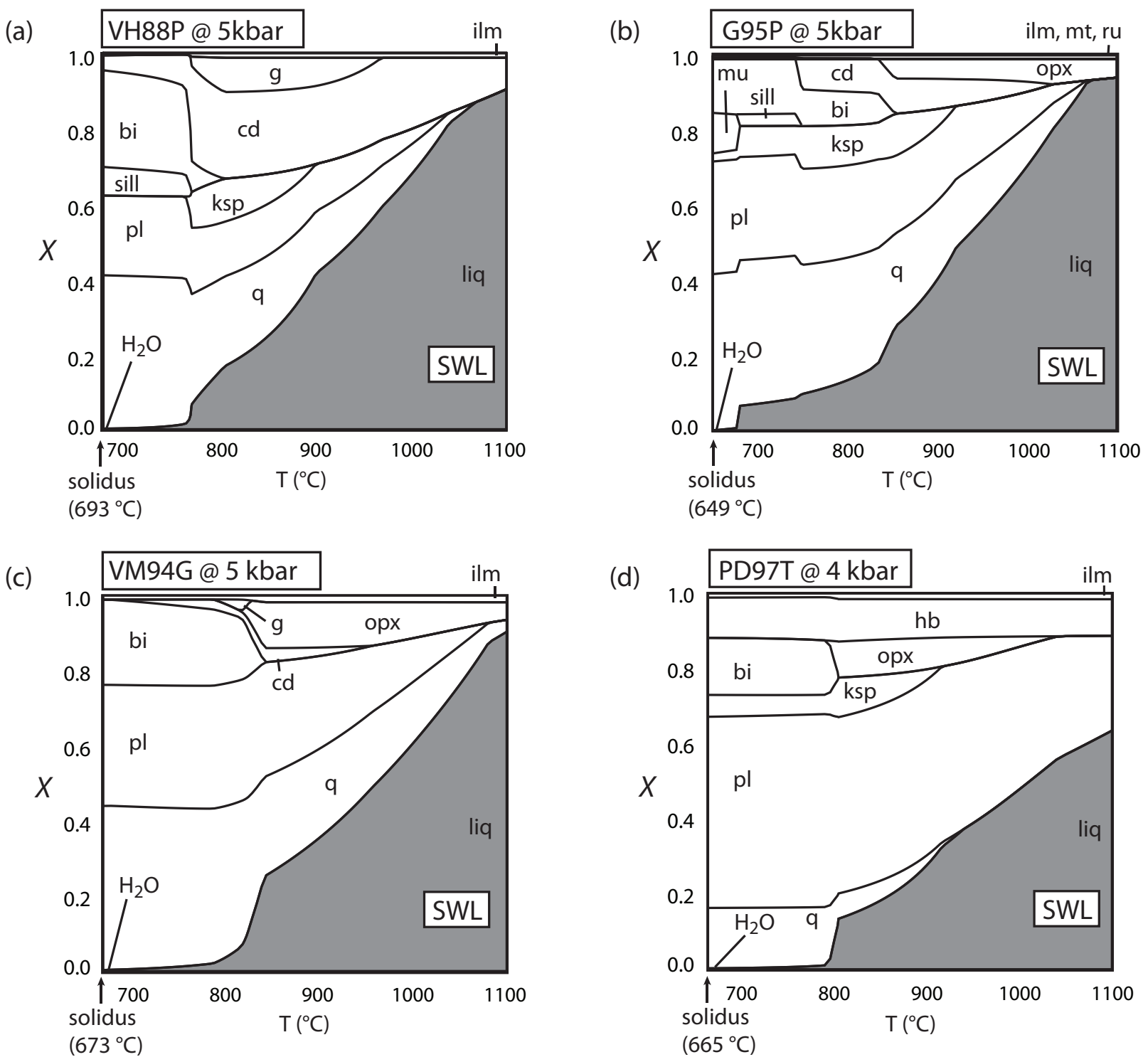

Figure 5. 


\section{Page 47 of 49}

(a)

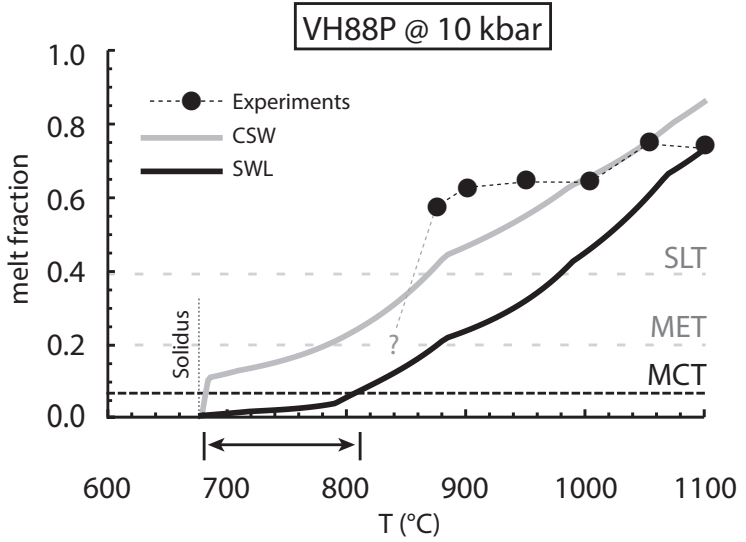

(c)

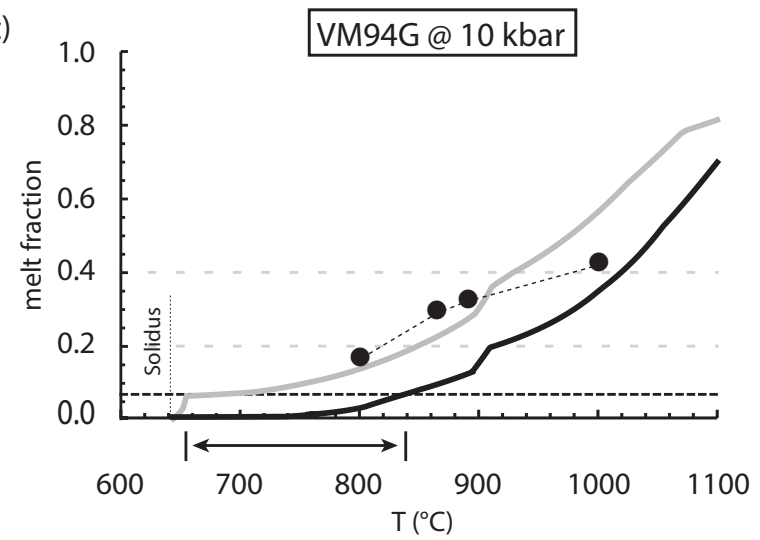

(b) $\quad$ G95P@ $10 \mathrm{kbar}$

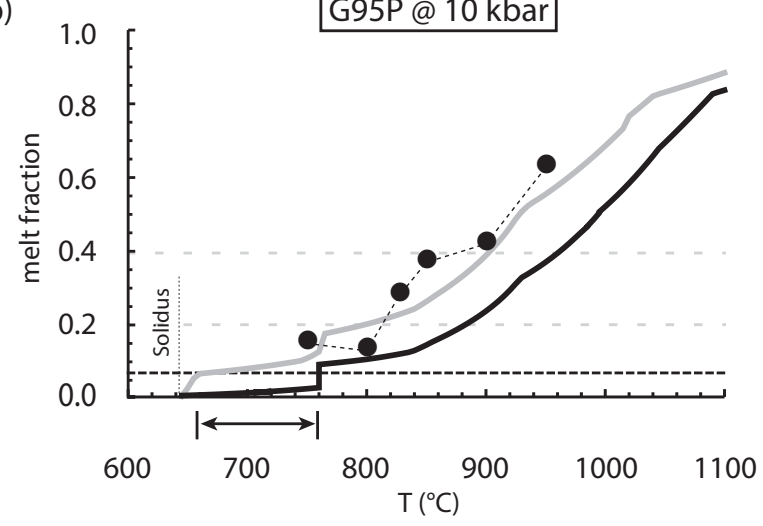

(d)

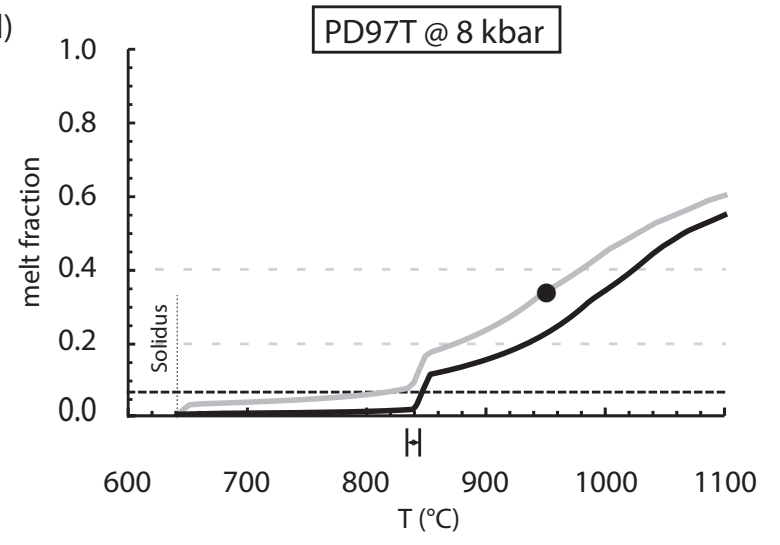

Figure 6 . 

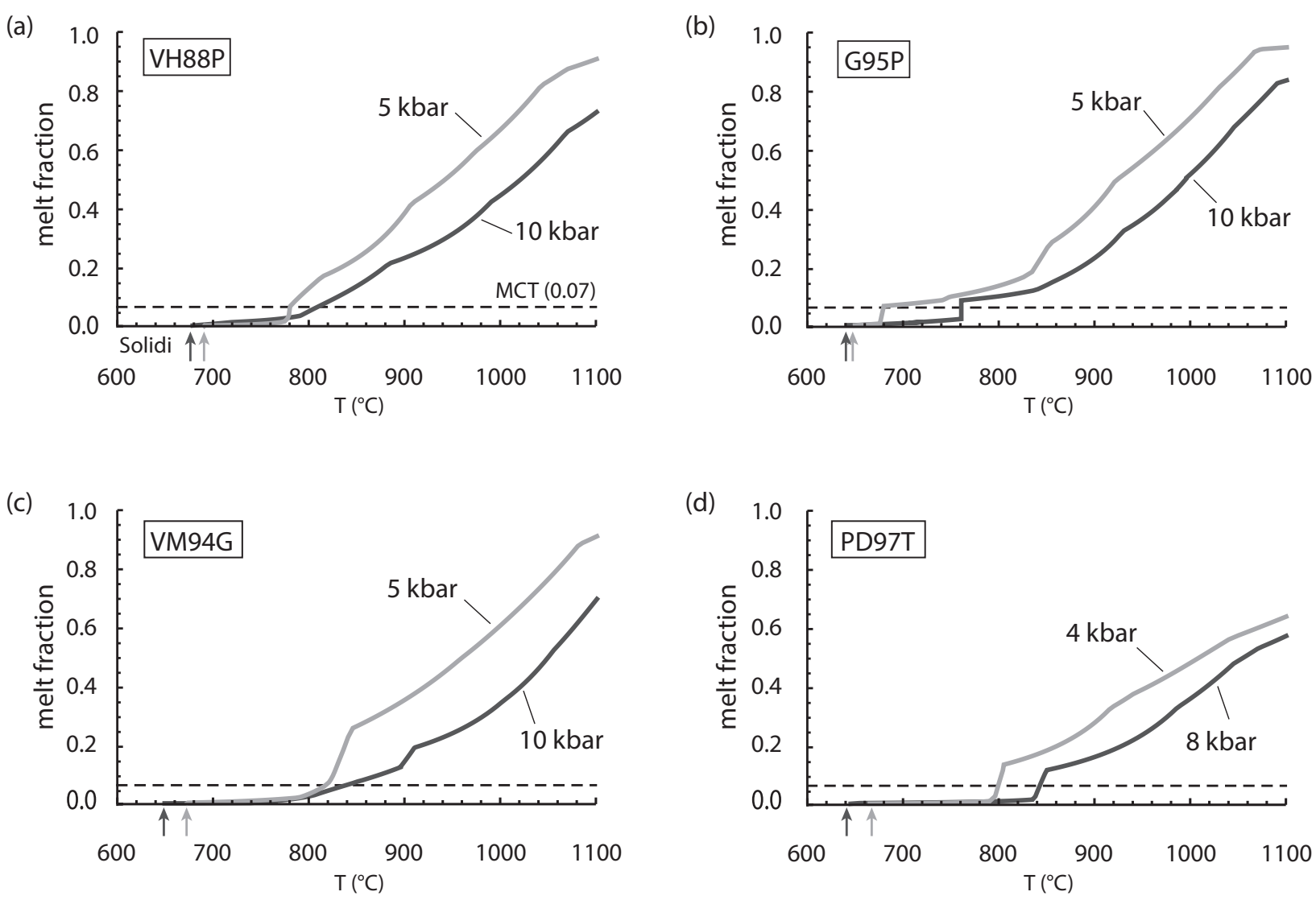

Figure 7. 


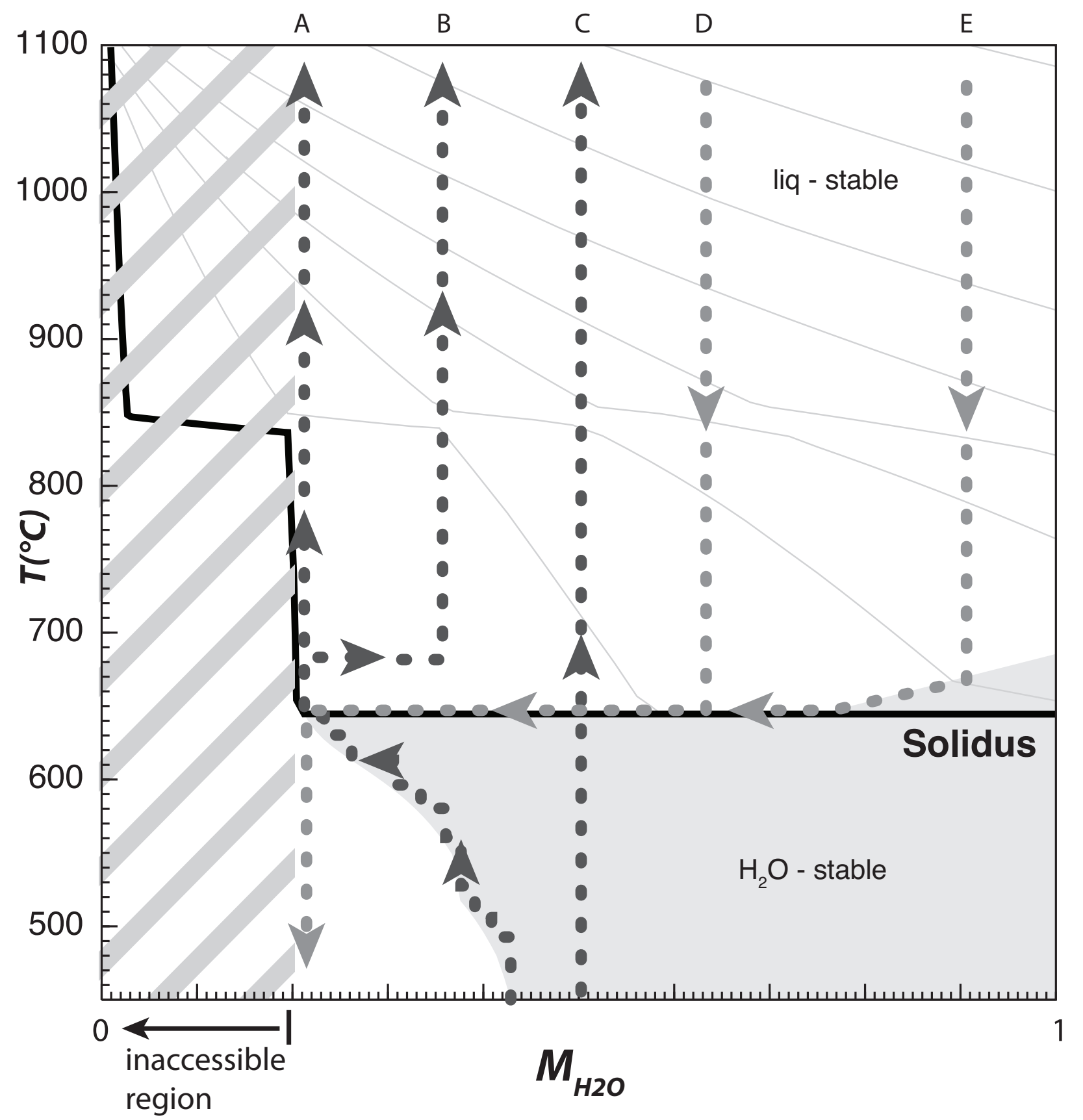

Figure 8 . 


\section{University Library}

\section{- M M N E R VA A gateway to Melbourne's research publications}

Minerva Access is the Institutional Repository of The University of Melbourne

Author/s:

Webb, G;Powell, R;McLaren, S

Title:

Phase equilibria constraints on the melt fertility of crustal rocks: the effect of subsolidus water loss

Date:

2015-02-01

\section{Citation:}

Webb, G., Powell, R. \& McLaren, S. (2015). Phase equilibria constraints on the melt fertility of crustal rocks: the effect of subsolidus water loss. JOURNAL OF METAMORPHIC GEOLOGY, 33 (2), pp.147-165. https://doi.org/10.1111/jmg.12114.

Persistent Link:

http://hdl.handle.net/11343/112394 